\title{
PREPOZYCI PREPOZYTURY KRAŚNICKIEJ KANONIKÓW REGULARNYCH LATERAŃSKICH OD FUNDACJI DO REFORMY W 1628 ROKU
}

\section{Informacji kilka o prepozyturze}

Prepozytura kraśnicka należała do późnośredniowiecznych fundacji kanoników regularnych kongregacji krakowskiej, którzy w grudniu I503 r. poprzez konfraternię z prepozyturą ołomuniecką nabyli przywileje kongregacji laterańskiej, ale laterańskimi zaczęli się nazywać dopiero na początku XVII w. ${ }^{I}$ Była pierwszą na ziemi lubelskiej placówką zakonną powstałą w ramach patronatu możnowładczego ${ }^{2}$. Metryka prepozytury sięga trzeciej ćwierci XV w. Jej fundatorem był Jan Rabsztyński z Tęczyna herbu Topór, syn Andrzeja Tęczyńskiego (+I46I) i Jadwigi z Książa Melsztyńskiej (+I457/I458) herbu Leliwa, mąż Barbary z Woli Konińskiej (+I509) herbu Rawicz, dziedzic włości kraśnickich od I466 r., zmarły jesienią I498 lub wiosną I499 r. ${ }^{3}$ Do fundacji klasztoru przyczynił się znacząco także jego stryj Jan Tęczyński (+I470) ${ }^{4}$. Według Jana Długosza to stryj był pomysłodawcą i miał nakłonić bratanka do osadzenia kanoników regularnych w Kraśnikư , ale rolę stryja w przedsięwzięciu zaznaczył również sam fundator, zwracając się do biskupa krakowskiego z prośbą o zatwierdzenie fundacji ${ }^{6}$. Dokument fundacyjny Jana Rabsztyńskiego informuje nadto, że myśl o osadzeniu zakonników przy kościele parafialnym w Kraśniku zrodziła się jeszcze za życia jego ojca Andrzeja

\footnotetext{
1 K. Latak, Kanonicy regularni laterańscy na Kazimierzu w Krakowie do końca XVI wieku, Ełk 1999, s. 73, 87-88; tenże, Kongregacja krakowska kanoników regularnych laterańskich na przestrzeni dziejów, Kraków 2002, s. 106-111; M. Wrzeszcz, Kraśnik, w: Encyklopedia Katolicka, t. 9, Lublin 2002, k. 1223-1225.

2 E. Zielińska, Kultura intelektualna kanoników regularnych św. Augustyna w Kraśniku w latach 1469-1583, Lublin 2002, s. 31-34; taż, Nekrolog klasztoru kanoników regularnych św. Augustyna w Kraśniku, „,Rocznik Lubelskiego Towarzystwa Genealogicznego", 2/2010, s. 79-125.

3 J. Kurtyka, Tęczyńscy. Studium z dziejów polskiej elity możnowładczej w średniowieczu, Kraków 1997, s. 571; E. Zielińska, Kultura intelektualna, s. 31-34.

4 Syn Andrzeja Tęczyńskiego i Anny Gorajskiej z Kraśnika. Urodził się najpewniej w 1409 r. Kasztelan biecki i wojnicki, starosta lubelski, kraśnicki, rabsztyński i chełmski, wojewoda sandomierski i krakowski, tenutariusz urzędowski i lubomelski. Uczestnik konfederacji Spytka z Melsztyna. Zmarł 6 VII 1470 r. w Krakowie. Zob. J. Kurtyka, Tęczyńscy, op. cit., s. 549-553.

5 J. Długosz, Liber beneficiorum dioecesis Cracoviensis [dalej: Lb], t. 3, s. 172.

6 „Ad id eciam charissimi Patrui mei Magnifici D[omi]ni] Johannis de Thenczyn Castellani Cracoviensis [...] votes et consiliis et intercessionibus solicitissimis moventibus, animum meum et voluntatem ad id libenter appono et presentibus realiter et effectualiter assentio [...]". Zob. Archiwum Narodowe w Krakowie [dalej: ANK], perg. 887.
} 
Tęczyńskiego, zamordowanego i6 lipca I46I r. w Krakowie, aczkolwiek nie udało się ustalić, czy projekt wiązał się od początku z kanonikami regularnymi i czy przeprowadzono już jakieś rozmowy w tej sprawie. Fundacja miała niewątpliwie charakter dewocyjny, jak napisał najlepszy znawca dziejów tego rodu Janusz Kurtyka, ale też była częścią świadomego dążenia Tęczyńskich z Rabsztyna do uświetnienia głównych ośrodków swych dóbr, jakimi były miasta Książ Wielki i Kraśnik. Klasztor kraśnicki z kościołem Najświętszej Maryi Panny miał być pomnikiem potęgi rodziny, co podkreślał program heraldyczny świątyni sięgający swą symboliką do czasów małżeństwa Andrzeja Tęczyńskiego (+I4II)7 z Anną Dymitrówną z Goraja $\left(+\right.$ I44I/I442) ${ }^{8}$ zawartego w I408 r. Na fasadzie jej kruchty południowej Jan Rabsztyński polecił umieścić obok wizerunku koronacji Najświętszej Maryi Panny herby Topór, Leliwa matki Jadwigi Ksiąskiej, Korczak babki ojczystej Anny Dymitrówny Gorajskiej i Rawicz żony Barbary z Woli Konińskiej’. Wyznaczone przez fundatora uposażenie miało zabezpieczyć byt dziewięciu zakonnikom - prepozytowi i ośmiu kanonikom ${ }^{\mathrm{I0}}$. Pierwsi kanonicy przybyli z klasztoru Bożego Ciała w podkrakowskim Kazimierzu, ufundowanego w marcu I405 r. przez króla Władysława Jagiełłę przy współudziale biskupa krakowskiego Piotra Wysza ${ }^{\mathrm{II}}$. Dokument fundacyjny prepozytury kraśnickiej, który odebrał prepozyt klasztoru krakowskiego ksiądz Jakub z Wadowic, został wystawiony w środę I8 maja I468 r. w Krakowie. Biskup krakowski Jan Lutek z Brzezia zatwierdził fundację i wybór pierwszego prepozyta dokonany przez kapitułę konwentu krakowskiego, a także przekazał kanonikom duszpasterstwo $\mathrm{w}$ istniejącej tu parafii dopiero dokumentem wystawionym w poniedziałek I3 marca I469 r. Nie udało się, jak dotąd, przekonująco dowieść, co było przyczyną tak długiego oczekiwania na biskupie potwierdzenie fundacji. Zatwierdzenie papieskie uzyskał konwent kraśnicki 9 kwietnia I $487 \mathrm{r}^{\mathrm{I} 2}$. Dokumenty fundacyjne zastrzegały, aby urząd prepozyta w Kraśniku pełnił zakonnik języka polskiego, a dyscyplina klasztorna i aktywność zewnętrzna odpowiadała we wszystkim dyscyplinie konwentu macierzystego w Kazimierzu ${ }^{13}$. Prepozytura, która stanowiła ważny element religijno-kulturalnego pejzażu ziemi lubelskiej, funkcjonowała 396 lat. Skasowały ją władze zaborcze carskiej Rosji (car Aleksander II) w nocy z 27 na 28 listopada I864 r. w ramach represji po Powstaniu Styczniowym. Zakonnicy poparli bowiem gremialnie zryw powstańczy, a dwóch z nich - ks. Walenty Pajdowski i ks. Szymon Sergiusz Pożyciński - wzięło w nim bezpośredni udział ${ }^{14}$. Ostatnim kanonikiem, który nowicjat odbył w klasz-

\footnotetext{
7 Andrzej Tęczyński, starosta podolski, kasztelan wojnicki, ojciec Andrzeja Tęczyńskiego zamordowanego 16 VII 1461 r. w Krakowie, dziad fundatora klasztoru kraśnickiego Jana Rabsztyńskiego z Tęczyna.

8 Anna z Goraja, córka Dymitra z Goraja, marszałka wielkiego koronnego, podskarbiego wielkiego koronnego, marszałka dworu króla Władysława Jagiełły, opiekuna młodej królowej Jadwigi Andegaweńskiej, uczestnika bitwy pod Grunwaldem. Zob. K. Myśliński, Dymitr z Goraja i początki Kraśnika, w: Problemy historii i archiwistyki, Warszawa 1986, s. 21-31.

9 J. Kurtyka, Tęczyńscy, op. cit., s. 501.

10 LB, t. 3, s. 172; K. Łatak, Kongregacja krakowska, op. cit., s. 107; E. Zielińska, Kultura intelektualna, op. cit., jw.

11 Tamże.

12 ANK, perg. 887, 889; Archiwum Klasztoru Bożego Ciała w Krakowie [dalej: ABC], Reformationes Conventuum, w: Summulae ex actis Capituli Generslis, rkps b. sygn.; Metrica Conventus, II, rkps b. sygn., s. 656-672; K. Łatak, Kongregacja krakowska, op. cit., s. 107; E. Zielińska, Kultura intelektualna, op. cit., s. 25-34; Archiwum Kapituly Katedralnej Sandomierskiej, opr. F. Kiryk, Sandomierz 2002, n. 93, s. 41-42.

13 ANK, perg. 887; Lb, t. 3, s. 172-173.

14 K. Łatak, Kongregacja krakowska, op. cit., s. 110; P.P. Gach, Kasaty klasztorów kanonickich, op. cit., s. 91-92;

E. Jabłońska-Deptuła, J. Grysakowa, Zaangażowanie patriotyczne zakonów męskich 1861-1864, op. cit., s. 130;
} 
torze kraśnickim i śluby zakonne złożył w tutejszym kościele był ksiądz Kazimierz Dionizy Gotz, zmarły w marcu 1909 r. w Chlinie koło Wolbromia ${ }^{15}$. Natomiast ostatnim kanonikiem pogrzebanym w Kraśniku był ksiądz Teodor Grzegorz Honorski, zmarły 3 września I858 r.

Nie dzieje jednakże prepozytury będą bezpośrednim przedmiotem niniejszego artykułu, chociaż ta dotąd nie doczekała się monografii, lecz jej rządcy od fundacji do reformy w pierwszej ćwierci XVII w. Użyteczności naukowej i praktycznej tego rodzaju publikacji nie trzeba zawile dowodzić. Jest ona oczywista zarówno w wymiarze historii konwentu, jak i w wymiarze historii parafii, miasta, gminy, powiatu i regionu. W ujęciu statutów klasztornych oraz komentarzy do nich prepozyt dla zakonników był wikariuszem Boga (et praepositus qui tibi sit loco Dei vicarius), w klasztorze zastępował Chrystusa (praepositus locum tenet Christi in monasterio ${ }^{16}$. Kto ubliża prepozytowi - odnotowano w średniowiecznym komentarzu do statutów, który w klasztorze kraśnickim czytano jeszcze w XVII w. - ubliża samemu Bogu ${ }^{17}$. Władza prepozyta nie była wprawdzie absolutna, ale bez niego nic się praktycznie nie działo w klasztorze. Dla miasta i całego szeregu okolicznych wsi prepozyt był proboszczem, chociaż w czynnościach parafialnych zastępował go zwykle kustosz kościoła, nazywany częściej zakrystianem ${ }^{18}$. Rządcy, a zatem prepozyci, bo o nich mowa, w sposób ewidentny wpływali na losy zgromadzenia, kierunki i formy jego aktywności, która w różnym stopniu, aczkolwiek zawsze, przekładała się na kulturę otoczenia. Oni formowali programy i zadania, decydowali o przyjmowaniu kandydatów, podejmowali decyzje, które w klasztorze i w środowisku pozostawiły konkretne ślady. Byli świadkami, ale nade wszystko współtwórcami historii prepozytury. Ich osobowość, talenty, kultura umysłowa i duchowa, a także koneksje miały decydujące znaczenie nie tylko dla funkcjonowania prepozytury ad intra, ale także dla jej roli kulturotwórczej i cywilizacyjnej w otoczeniu bliższym i dalszym. Wielu z nich należało bez wątpienia do postaci wybitnych na tle swej epoki ${ }^{19}$. Tymczasem zaledwie kilku doczekało się biogramów czy wzmianek w różnego rodzaju słownikach, leksykonach i encyklopediach, a są niestety również tacy, których historiografia wcale nie zna albo zna zaledwie z nazwiska.

W dziejach prepozytury kraśnickiej można wyróżnić dwa okresy o dość wyraźnej cezurze czasowej kanonicznej i problemowej. Pierwszy rozciąga się od fundacji w I468 r. do reformy przeprowadzonej w I620 r. pod naciskiem biskupa Marcina Szyszkowskiego, kiedy prepozytura była jednostką autonomiczną, a z prepozyturą macierzystą w Krakowie i pozostałymi jej filiami łączyły ją więzy określone ściśle dokumentami zawieranych od I480 r. konfraterni. Drugi natomiast obejmuje lata od reformy przeprowadzonej w I620 r. na mocy bulli z 25 maja I6I8 r. papieża Pawła V, która pozbawiła prepozyturę autonomii i podporządkowała ją prepozytowi prepozytury macierzystej i kapitule generalnej formalizowanej kongregacji, do

\footnotetext{
E. Nebelski, Nieprzejednani wrogowie Rosji. Duchowieństwo lubelskie i podlaskie w Powstaniu 1863 roku i na zestaniu, Lublin 2008, s. 145, 193.

$15 \mathrm{ABC}$, Catalogus fratrum defunctorum Canonicorum Regularium Lateranensium Congregationis Cracoviensis ab introductione Cracoviam scilicet ab Anno 1405, rkps b. sygn.; Memoriale fratrum et benefactorum defunctorum Congregationis Cracoviensis Canonicorum Regularium Lateranensium, rkps b. sygn.

16 K. Latak, Kongregacja krakowska, op. cit., s. 141-142.

17 Tamże, s. 142.

18 Tamże.

19 Prepozyci: Michał, Andrzej ze Słupczy, Albert Tarnovita, Jan Chryzostom Korsak, Benedykt Adam Szamotulski, Aleksander Michał Galiński, Jan Herkulana ex Dowmont Matuszewicz, Antoni Firmin Lubaczewski.
} 
kasaty w I864 r. W pierwszym okresie urząd prepozyta, zgodnie z ówczesnymi statutami, był dożywotni, aczkolwiek możliwe było ustąpienie dobrowolne oraz złożenie kanoniczne z urzędu. Wyboru prepozyta dokonywała kapituła lokalna, ale wybór musiał uzyskać zatwierdzenie biskupa krakowskiego ${ }^{20}$. O zatwierdzenie wyboru występowała do biskupa kapituła konwentualna albo sam elekt, który do supliki musiał dołączyć akt wyboru podpisany przez ojców kapitulnych. Rezygnację z urzędu prepozyt przedkładał nie kapitule konwentualnej, lecz biskupowi. Akt rezygnacji, co dla prepozytury kraśnickiej potwierdza kazus prepozyta Andrzeja z Bodzentyna (I53I-I535), spisywali notariusze oficjalatu w Sandomierzu. W okolicznościach uzasadnionych i po przeprowadzonej wizytacji mógł też sam biskup złożyć prepozyta z urzędu. Czasami, co poświadcza kazus prepozyta Marcina z Mielca (1594-I607), stosowano rozwiązanie polubowne. Prepozyt pod presją argumentów sam składał rezygnację, zaś biskup ją łaskawie przyjmował. Po I620 r. o obsadzie urzędu prepozyta decydowała nie tyle kapituła lokalna, co prepozyt prepozytury macierzystej w Krakowie i kapituła generalna, w której uczestniczyli przedstawiciele kapituły lokalnej. Prośbę o zatwierdzenie wyboru i kanoniczną instytucję prepozyta przedkładał biskupowi prepozyt generalny kongregacji. Kilka takich dokumentów zachowało się w archiwum krakowskiej kurii biskupiej ${ }^{21}$. W I628 r. przyjęto, że urzędem dożywotnim w zgromadzeniu będzie wyłącznie urząd prepozyta generalnego kongregacji, natomiast kadencja prepozytów lokalnych będzie trwała trzy lata. Odtąd na początku kapituły generalnej prepozyci lokalni składali zarówno dokument poświadczający ich poprzedni wybór wystawiany przez prepozyta generalnego kongregacji, jak też dokument instytucji biskupiej ${ }^{22}$. Po zamknięciu kapituły dokumenty te najprawdopodobniej niszczono, gdyż w archiwum prepozytury macierzystej nie zachowały się ich egzemplarze. W niniejszym artykule pod uwagę wzięliśmy jedynie rządców prepozytury w pierwszym okresie jej dziejów, gdyż jest to okres jak dotąd w niewielkim stopniu rozpoznany, a w konsekwencji słabiej reprezentowany w literaturze naukowej. Podstawę rekonstrukcji chronologii życia i aktywności rządców prepozytury stanowiły głównie materiały archiwalne przechowywane między innymi w archiwum parafii kraśnickiej, w archiwum klasztoru Bożego Ciała kanoników regularnych laterańskich w Krakowie, w Archiwum Krakowskiej Kurii Metropolitalnej, w Archiwum Metropolitalnym w Lublinie, w Archiwum Diecezjalnym w Sandomierzu, w Archiwum Narodowym w Krakowie, w zbiorach Biblioteki Jagiellońskiej, w zbiorach Biblioteki Czartoryskich, w zbiorach Biblioteki PAN/PAU w Krakowie, Archiwum Państwowym w Lublinie i innych.

\section{Rządcy prepozytury}

\section{Ksiądz Jan z Bytomia (1468/69-1470)}

Mistrz Jan Długosz nazwał go kamieniem węgielnym i zasadźcą konwentu kraśnickiego ${ }^{23}$. Jego rodzicami mogli być Barbara i Michał Fleyschetyn z Bytomia, wpisani w nekrologu

\footnotetext{
20 K. Łatak, Kongregacja krakowska, op. cit., s. 141-142.

21 Archiwum Kurii Metropolitalnej w Krakowie [dalej: AKMKr], Producta, rkps, b. sygn.

22 ABC, Acta Capituli Generalis Conventus S[acrati]s[simi] Corporis Christi Casimiriae ad Cracoviam Canonicorum Regularium S[ancti] Augustini, rkps b. sygn., k. 5.

23 LB, t. 3, s. 172. Zob. także: S. Ranatowicz, Casimiriae civitatis, op. cit., k. 16v, 17v; E. Zielińska, Kultura intelektualna, op. cit., s. 64; J. Kurtyka, Tęczyńscy, op. cit., s. 501.
} 
prepozytury krakowskiej wśród znaczniejszych jej dobrodziejów ${ }^{24}$. Nauki początkowe przyszły prepozyt kraśnicki pobierał zapewne w Bytomiu. Do zakonu miał wstąpić w Krakowie po studiach uniwersyteckich i w tym samym czasie co święty Stanisław Kazimierczyk (I433-I489) ${ }^{25}$. Identyfikuję go zatem z Janem z Bytomia (de Beythom), który w lutym I460 r., za dziekanatu magistra Jana z Olkusza, uzyskał bakalaureat na Wydziale Artium Uniwersytetu Krakowskiego $^{26}$. Nowicjat odbył i śluby zakonne złożył w klasztorze krakowskim nie później niż w I462 r. Prepozytem klasztoru był wówczas ksiądz Gaspar Polak (I439-I464), a konwent tworzyli m.in. znakomity kopista ksiądz Salomon Wierzbanowicz (+I484) oraz cieszący się sporym uznaniem malarz tablicowy brat Jan z Nysy. Święcenia kapłańskie otrzymał ok. I463 r., albowiem formacja seminaryjna kandydatów posiadających stopnie akademickie trwała wówczas w klasztorze nie dłużej niż dwa lata ${ }^{27}$. W I468 r. prepozyt Jakub z Wadowic, z którym Jan Rabsztyński z Tęczyna i jego stryj Jan Tęczyński uzgadniali fundację w Kraśniku, wskazał go jako kandydata na urząd prepozyta, co sugeruje, że odznaczał się zarówno odpowiednią kulturą duchową i umysłową, jak i niepoślednimi umiejętnościami administracyjnymi. W Kraśniku istniała już co prawda parafia, ale w budowie był gotycki kościół ${ }^{28}$, a klasztor trzeba było wznosić od fundamentów. Rozbudowę kościoła i budowę klasztoru finansowała bez wątpienia rodzina fundatora, niemniej równie ważne i przydatne były kompetencje rządcy konwentu. Biskup krakowski Jan Lutek z Brzezia zatwierdził jego wybór I3 marca I469 r $^{29}$. Czy prepozyt osiadł w Kraśniku przed tą datą czy dopiero po biskupiej inwestyturze, trudno jednoznacznie odpowiedzieć. W każdym razie pierwsza wzmianka źródłowa potwierdzająca jego aktywność na urzędzie pochodzi dopiero z 8 lutego I470 r., gdy pojawił się w konsystorzu oficjała w Lublinie ${ }^{30}$. W dotychczasowej literaturze naukowej przyjmowano, że prepozyt zarządzał klasztorem jeszcze w marcu I49I r. Jego zabiegom przypisywano rozbudowę monumentalnej świątyni oraz budowę klasztoru. Dopiero na przełom lat I498/I499 datowano jego dymisje i powrót do klasztoru krakowskiego, zaś śmierć na 1507 r. w Krakowie ${ }^{31}$. Tymczasem ponowna analiza akt bi-

\footnotetext{
24 Wpisywanie rodziców zakonników do nekrologu nie było wówczas odosobnioną praktyką, a potwierdzają ją m.in. przypadki prepozyta Gaspara Polaka, prepozyta Jakuba z Wadowic, ks. Mikołaja Davidis, ks. Mikołaja Lammela, ks. Pawła Tylicha czy w końcu konwersa Mikołaja Preischwicza. Zebrany materiał źródłowy do dziejów klasztoru zdaje się przekonywać, że przy okazji profesji zakonnej lub święceń kapłańskich rodzice zakonnika przekazywali klasztorowi równowartość części spadku, która jemu się należała. Czasem były to sumy wcale nie małe, stąd rodziców wpisywano do nekrologu jako umiłowanych dobrodziejów konwentu.

25 Opinia ks. Krzysztofa Łoniewskiego znajdująca się w żywocie świętego opublikowanym w $1617 \mathrm{r}$.

26 Ksiega promocji Wydziału Sztuk Uniwersytetu Krakowskiego z XV wieku, wyd. A. Gąsiorowski, Kraków 2000, s. $49,60 / 22$.

27 K. Łatak, S. Nalbach, Ze studiów nad kulturq umystowa, op. cit., s. 125.

28 Budowę kościoła rozpoczęto po 1443 r., a przed 1450 r. Budowę finansował Andrzej Tęczyński, a nadzorował proboszcz ks. Andrzej Kaliński, który zmarł wiosną 1468 r. Gdy kanonicy przybyli do Kraśnika, kościół był wzniesiony w części obecnego prezbiterium i zakrystii. Mistrz Jan Długosz budowlę musiał widzieć osobiście, gdyż w 1450 r., jak nadmienił w Liber beneficiorum, towarzyszył kard. Zbigniewowi Oleśnickiemu i asystował mu w czasie konsekracji kościoła w pobliskim Batorzu, który został wzniesiony również z fundacji Andrzeja Tęczyńskiego.

29 ANK, Perg. 889.

30 Archiwum Archidiecezji Lubelskiej [dalej: AAL], Acta consistori foranei Lublinensi, sygn. 3, s. 12.

31 E. Zielińska, Kultura intelektualna, op. cit., s. 31, 64-65; taż, Nekrolog, s. 87; K. Latak, Kongregacja krakowska, op. cit., s. 111; K. Łatak, S. Nalbach, Ze studiów nad kultura umysłowa, op. cit., s. 125; S. Gołub, Kościót p.w. Wniebowzięcia NMP w Kraśniku - wyniki badań archeologicznych, w: Kościoly, cerkwie i klasztory Lubelszczyzny w świetle badań archeologicznych, red. E. Banasiewicz-Szykuła, Lublin 2013, s. 11-35.
} 
skupów krakowskich z lat I466-I47I zaskoczyła zapisem sądowym z dnia I7 lipca I470 r. odnoszącym się sprawy opactwa cysterskiego w Koprzywnicy, w którym wzmiankuje się również prepozyta klasztoru w Kraśniku, ale o imieniu Augustyn ${ }^{32}$. Jeśli w zapisie nie zaszła pomyłka co do imienia prepozyta, to przyjąć należy, że pierwszy prepozyt kraśnickiego klasztoru sprawował rządy niewiele ponad rok. Nekrolog kraśnicki oraz nekrolog krakowski nie wymieniają wśród zmarłych konfratrów w XV w. prepozyta kraśnickiego o imieniu Jan, co oznacza w zasadzie jedno, a mianowicie, że wycofał się z Kraśnika i powrócił do Krakowa. Mistrz Jan Długosz w opisie parafii i klasztoru w Kraśniku nie wspomniał wprawdzie o wymianie na stanowisku prepozyta, aczkolwiek o księdzu Janie z Bytomia napisał w czasie przeszłym dokonanym ${ }^{33}$.

\section{Ksiądz Augustyn (1470)}

Prepozyta o imieniu Augustyn nie zna dotychczasowa literatura naukowa poświęcona klasztorowi. Nie wymieniają go również zachowane nekrologi klasztorów kraśnickiego i krakowskiego. Wzmiankują go natomiast akta biskupa krakowskiego Jana Lutka z Brzezia. We wtorek I7 lipca I470 r. w Złotej pod Sandomierzem biskup rozsądzał spór pomiędzy opatem cystersów koprzywnickich Mikołajem Trebnicem (I452-I474) a szlachetnymi Stanisławem Szyrkiem i Stanisławem Zemłą ze wsi Rczyszyn (Rczischin) oraz Prandotą wójtem w Zakrzowie o należne opactwu dziesięciny. W procesie wystąpił również ksiądz Augustyn prepozyt klasztoru w Kraśniku, gdyż dziesięciny z łanów wójtowskich w Zakrzowie, zgodnie z wolą fundatora klasztoru, należały się kościołowi w Kraśniku34. Jeśli zatem, co już zasygnalizowałem wyżej, w zapisie nie zaszła pomyłka co do imienia prepozyta, to należy przyjąć, że po 8 lutego, a przed I7 lipca I470 r. prepozyt Jan z Bytomia usunął się z Kraśnika, a jego miejsce zajął ksiądz Augustyn. Kanonik o tym imieniu, pochodzący z Krakowa, występował w składzie konwentu krakowskiego od połowy XV w. Jego rządy w Kraśniku nie trwały jednak dłużej niż trzy lata. W każdym razie w poniedziałek II lutego i w piątek 22 lutego I474 r. w konsystorzu lubelskim występował już prepozyt o imieniu Jan ${ }^{35}$. Ks. Augustyn musiał zrezygnować z urzędu, bo nie sposób przyjąć, że zapomniano go wpisać do nekrologu krakowskiego. Po rezygnacji powrócił do Krakowa. Od I3 marca I476 r. reprezentował czasem prepozyta Jakuba z Wadowic w różnych urzędach, w tym w konsystorzu krakowskim ${ }^{36}$. Zmarł w klasztorze krakowskim W styczniu I485 lub I486 r.37

\footnotetext{
32 AKMKr, Acta episcopalia, t. 1, k. 40.

33 „Eratque monasterii praefati in Crasznyk primarius praepositus et lapis Johannes de Beythom frater ordinis et monasterii praefati, qui cum aliis fratribus ex monasterio Corporis Christi de Casimiria in adiutorium sibi per fratrem Jacobum Corporis Christi praepositum datis, primum monasterium in Crasznyk annis pluribus rexit et utiliter gubernavit". Zob. LB, t. 3, s. 172.

$34,,[. .$.$] quas religiosus dns Augustinus prepositus monasterii in Crasznyk fideliter decimabit apud ipsos advoca-$ tos.... Ipse Augustinus prep[osi]tus de Crasznyk [...]”. Zob. AKMKr, Acta episcopalia, t. 1, k. 40.

35 AAL, Acta Consistorii Foranei Lublinensi, 4, k. 232v.

36 AKMKr, Acta officialia, t. 13, s. 767.

37 ANK, ms K 888, n. 1; Biblioteka Główna Uniwersytetu Marii Curie-Skłodowskiej w Lublinie (dalej: BGUMCS), rkps sygn. III 608, s. 74 .
} 


\section{Ksiądz Jan z Piekar (1473/1474-1497)}

Na urzędzie prepozyta kraśnickiego wymieniany od II lutego I474 r., gdy przed oficjałem konsystorza lubelskiego toczył spór sądowy z Michałem, klerykiem szkoły w Lublinie ${ }^{3}$. Życie zakonne rozpoczynał bez wątpienia w klasztorze krakowskim nie wcześniej niż na przełomie lat pięćdziesiątych i sześćdziesiątych XV w. Jako prepozyt był dość aktywny. Konfraternią zawartą w środę 3I maja I480 r. i potwierdzoną we wtorek 30 sierpnia I484 r. uregulował wzajemne relacje z prepozyturą macierzystą w Krakowie ${ }^{39}$. W I485 r. rozpoczęto starania o papieską konfirmację fundacji, które poparł zarówno fundator, jak też biskup krakowski Jan Rzeszowski. Papież Innocenty VIII dokumentem wystawionym 9 lutego I486 r. wyznaczył opata cystersów koprzywnickich Jana Trebnica do przeprowadzenia procedury konfirmacyjnej. Procedura trwała ponad rok. Dokument konfirmacyjny został wystawiony w czwartek 9 kwietnia I487 r. i zapewne w tym samym miesiącu był promulgowany w Kraśniku ${ }^{40}$. W latach osiemdziesiątych XV w. klasztor zaczął przyjmować nowicjuszy. Przed I500 r. progi furty klasztornej przekroczyli na pewno kanonicy: Stanisław, Michał, Maciej, Albert, Jakub, Jan, Piotr oraz Tomasz. W tym samym okresie, jak pozwala domniemywać nekrolog krakowski, zmarło w Kraśniku siedmiu zakonników - ks. Marcin, jako pierwszy, a następnie brat Stanisław, ks. Stanisław, przeor i zakrystian Mikołaj, ks. Mikołaj z Sandomierza, ks. Tomasz, ks. Jakub oraz ks. Piotr. Nekrolog krakowski nadmienił, że dwóch spośród zmarłych - ks. Piotr i ks. Tomasz - zostało porwanych przez Tatarów (capti per Tartharos). Chodzi tu bez wątpienia o najazd tatarski w I498/I499 r., w czasie którego spalono również kościół w Urzędowie ${ }^{4}$. Zakonnicy obok modlitwy i obowiązków parafialnych uprawiali z powodzeniem także sztukę pisania, czego pozostałością jest m.in. kodeks z tekstem kilku traktatów teologicznych oraz nekrologiem, przechowywany dzisiaj w zbiorach Biblioteki Głównej Uniwersytetu Marii Curie-Skłodowskiej. W kodeksie znalazł się tekst statutów, który jak się okazało, jest jedynym dla obediencji krakowskiej z okresu przedtrydenckiego, jaki się zachował ${ }^{42}$. Zadbał prepozyt o miejscową szkołę, jej rektorowi wypłacał pięć grzywien ${ }^{43}$. W aktach konsystorza lubelskiego pod datą I września I473 r. odnotowano Michała, nauczyciela w szkole kraśnickiej, który toczył spór sądowy z proboszczem ostrowskim Leonardem, a pod datą 7 października I473 r. Jana, kleryka z Kraśnika, który toczył spór sądowy z Michałem ze szkoły kraśnickiej44. Na Wydziale Artium Uniwersytetu Krakowskiego studia podjęło w tym czasie dwóch studentów z Kraśnika, którzy nauki początkowe

\footnotetext{
38 AAL, Acta consistorii foranei Lublinensi (1465-1480), sygn. 4, k. 230, 232v.

39 ABC, Dokumenty pergaminowe, sygn. 108; BGUMCS rkps sygn. III 608, s. 74; E. Zielińska, Filia fidelis. Klasztor Kanoników Regularnych w Kraśniku a klasztor Kanoników Regularnych w Kazimierzu w drugiej połowie XV i pierwszej połowie XVI wieku, w: Klasztor Bożego Ciała Kanoników Regularnych Laterańskich w Krakowie w okresie przedtrydenckim. Ludzie, wydarzenia, budowle, kultura, red. K. Łatak, Łomianki 2012, s. 365-377.

40 Archiwum Kapituły Katedralnej Sandomierskiej (dalej: AKKS), Zbiór dokumentów pergaminowych, sygn. 93; ADL, Acta consistorii foranei Lublinensi, sygn. 60, s. 192-204; ABC, Reformationes Conventuum, w: Summulae ex actis Capituli Generalia, rkps b. sygn., s. 131-138; Metrica Conventus Sacratissimi Corporis Christi, rkps b. sygn., s. 643-646, 656-672; Archiwum Kapituly Katedralnej Sandomierskiej, opr. F. Kiryk, Sandomierz 2002, s. 41-42. Dokument był oblatowany 1 IV 1585 r. w Urzędowie i 6 IX 1610 r. w Sandomierzu.

41 A. Walewander, Kronika klęsk elementarnych $w$ Polsce w latach 1450-1586, Lwów 1915, s. 82; P. Jusiak, Najazdy tatarskie na ziemię chetmska i lubelska w XV i pierwszej Polowie XVI wieku oraz ich skutki, passim.

42 BGUMCS, sygn. III 600.

43 LB, t. 3, s. 173; E. Zielińska, Kultura intelektualna, op. cit., s. 45.

44 ADL, Acta consistorii foranei Lublinensi, syg. 4, s. 211, 217.
} 
pobierali być może w szkole kraśnickiej - Piotr, syn Mikołaja, w I477 r. oraz Mikołaj, syn Grzegorza, w I486 r. Piotr był później altarzystą w kościele Mariackim w Krakowie5. Dnia I marca I49I r. prepozyt, w towarzystwie ks. Macieja, zjawił się w konsystorzu w Lublinie, by dopełnić umowy z miejscowymi mistrzami kamieniarskimi Stanisławem i Marcinem ${ }^{46}$. W Kraśniku trwały prace budowlane i potrzebny był kamień ciosany, który kamieniarze zgodzili się dostarczyć na Zielone Świątki. Zapis w aktach konsystorskich jest ostatnią, znaną na dzisiaj, imienną wzmianką źródłową poświadczającą aktywność prepozyta w Kraśniku, aczkolwiek to bez wątpienia także on przyjmował zapisy od Doroty z Opola, wdowy po Bartłomieju, dziedzicu Leśnika, wpisane do akt konsystorza w Sandomierzu 2 maja I49I r., o których wspomina notata prepozyta Michała sporządzona W I504 r. ${ }^{47}$ W sobotę 27 stycznia I497 r. prepozyt pojawił się w konsystorzu w Krakowie przed oficjałem Janem z Szebni i przedłożył rezygnację z urzędu, która została przyjęta ${ }^{48}$. Okoliczności rezygnacji nie są znane. Po rezygnacji prepozyt przeniósł się do Krakowa. Zmarł I6 lutego I507 r. w klasztorze krakowskim na urzędzie podprzeora, który to urząd łączono z urzędem mistrza nowicjatu ${ }^{49}$.

\section{Ks. Michal (1497-ok. 1515)}

Był profesem miejscowym. Z tytułem prepozyta został wymieniony po raz pierwszy 4 maja I50I $r^{50}$ Wybór na urząd musiał jednak nastąpić nie później niż w lutym I497 r. W chwili wyboru musiał być po święceniach kapłańskich i posiadać pewien staż życia klasztornego. Z biografii świętego Stanisława Kazimierczyka wiemy, że w tamtym czasie w zgromadzeniu nie dopuszczano do urzędów, jeśli od święceń zakonnika nie upłynęło pięć lat. Pozwala to szacować, że w chwili wyboru ksiądz Michał miał nie mniej niż 30 lat. Jego przyjście na świat datuję zatem na ok. I460 r., a wstąpienie do klasztoru na ok. I485 r. W okresie jego prepozytury konwent liczył ośmiu zakonników in sacris i co najmniej jednego konwersa. $\mathrm{Z}$ prowadzonych prac wymienić trzeba dokończenie rozpoczętej za rządów prepozyta Jana rozbudowy kościoła oraz fundację ołtarza głównego, który konsekrował w niedzielę 22 marca I506 r. biskup przemyski Maciej Drzewicki, późniejszy prymas. Ołtarz dedykowano Najświętszej Maryi Pannie Wniebowziętej, św. Annie, Nawróceniu św. Pawła Apostoła, św. Stanisławowi Biskupowi oraz św. Augustynowi ${ }^{51}$. Zestawienie zebranych dotąd informacji źródłowych przekonuje, że ołtarz, który był tryptykiem i w centralnej swej części przedstawiał scenę koronacji Najświętszej Maryi Panny, został wykonany w Krakowie, a finansowali go Tęczyńscy - Barbara oraz synowie Jan i Andrzej. Jesienią 1502 r. Tatarzy znów wdarli się do Polski i przeszli także przez Kraśnik, rujnując miasto. Nadmienił o tym

\footnotetext{
45 Wzmianki w latach 1480-1482. Zob. AKMkr, Acta Episcopalia, t. 3, k. 201.

46 ADL, Acta consistorii foranei Lublinensis, sygn. 5, s. 253.

47 Biblioteka Narodowa w Warszawie [dalej: BN], rkps sygn. III 8044, k. 79. Zapis szczegółowo omówiła E. Zielińska, Kultura intelektualna, op. cit., s. 54.

48 AKMKr, Acta Officialia, t. 18, s. 537.

49 ANK, ms K 888, n. 70; BUMCS III 608, s. 74; ABC, Memoriale, s. 47; K. Latak, Kongregacja krakowska, op. cit., s. 111; E. Zielińska, Kultura intelektualna, op. cit., s. 63-64; K. Latak, S. Nalbach, Ze studiów nad kultura umystowa, op. cit., s. 125.

50 ABC, Reformationes Conventuum, s. 158, 159; E. Zielińska, Kultura intelektualna, op. cit., s. 51, 67.

51 E. Zielińska, Znaleziska w oltarzach kościoła Wniebowzięcia Najświętszej Maryi Panny w Kraśniku, w: Kościót Wniebowzięcia Najświętszej Maryi Panny w Kraśniku, red. J. Zamorski, Kraśnik 2013, s. 67.
} 
Marcin Bielski w swojej kronice ${ }^{2}$. Zniszczenia musiały być dotkliwe, sięgające podwalin, skoro w 1504 r. Jan Rabsztyński, nadworny królewski i dziedzic dóbr kraśnickich, przedłożył królowi Aleksandrowi Jagiellończykowi prośbę o zwolnienie z podatków z tej racji. Król, przychylając się do prośby, przyznał miastu z przyległymi wsiami zwolnienie podatkowe na osiem lat. W I505 r. zmarł Jan Rabsztyński, syn fundatora, a Kraśnik przeszedł w ręce jego brata kanonika Andrzeja, aczkolwiek spory wpływ na zarząd dobrami miała jego matka Barbara z Woli Konińskiej, dworka królowej Elżbiety Rakuszanki i ochmistrzyni dworu królewny Elżbiety53. W czwartek I maja I508 r. Barbara Rabsztyńska z kanonikiem Andrzejem zapisali klasztorowi dochody z cła w Kraśniku i Urzędowie, co odrębnym dokumentem wystawionym w środę I3 września tego roku w Trokach potwierdził król Zygmunt Stary ${ }^{54}$. Dnia 9 lutego I509 r. prepozyt w towarzystwie Barbary Rabsztyńskiej i kanonika Andrzeja Rabsztyńskiego pojawił się osobiście w oficjalacie w Krakowie, by darowiznę wpisać do akt kościelnych 55 . Zapis ten kojarzę z kontynuacją prac przy kościele i budowie klasztoru. Niestety w 509 r. zmarli zarówno Barbara Rabsztyńska, jak i jej syn kanonik Andrzej Rabsztyński. Kraśnik przejęła Zofia z Tęczyńskich Słaboszowa, ciotka kanonika Andrzeja, która w lipcu I5Io r. odstąpiła dobra kraśnickie Annie z Woli Konińskiej, wdowie po Gabrielu Tęczyńskim, kuzynie Rabsztyńskich, oraz jej synom Janowi i Stanisławowi ${ }^{6}$. Wygaśnięcie rodziny fundatorskiej i przejecie miasta przez ich kuzynów chyba nie odbiło się znacząco na fundacji, aczkolwiek początki niekoniecznie musiały być spokojne. Pod patronatem Jana Gabrielowica Tęczyńskiego kontynuowano prace przy budowie klasztoru i nad wystrojem wnętrza kościoła. Dnia I5 lipca I5Io r. prepozyt stawił się w oficjalacie w Krakowie, by ustanowić ks. Piotra z Lwówka, prokuratora causarum klasztoru krakowskiego, pełnomocnikiem klasztoru kraśnickiego w sprawach z malarzem Joachimem z Krakowa i innymi ${ }^{57}$. W czasie tego pobytu w Krakowie prepozyt najprawdopodobniej uzgodnił z malarzem malowanie wnętrza rozbudowanego kościoła, a na wypadek kwestii spornych ustanowił pełnomocnika, by samemu nie podróżować do Krakowa. Malowanie kościoła, jak informuje odkryty niedawno napis w prezbiterium, ukończono w połowie października I5I2 r. ${ }^{5} \mathrm{~W}$ I504 r., jak się wydaje, porządkowano również archiwum i bibliotekę klasztorną. Śladem tego są kodeks z nekrologiem przechowywany dzisiaj w Bibliotece Uniwersytetu Marii Curie-Skłodowskiej oraz notaty prepozyta spisane w tymże roku na kartach jednej z ksiąg. Notaty zawierają informacje o legatach na rzecz klasztoru z lat I49I-I504 i wynikających z nich pobożnych zobowiązań, udzielonych pożyczkach i dłużnikach klasztornych, gospodarce klasztoru,

\footnotetext{
52 J. Kurtyka, Tęczyńscy, op. cit., s. 580.

53 Tamże, s. 572-573, 578-580.

54 ABC, Reformationes Conventuum, s. 155-156; E. Zielińska, Kultura intelektualna, op. cit., s. 53.

55 ABC, Reformationes Conventuum, s. 156-158; Metrica Conventus, II, s. 646-653.

56 J. Kurtyka, Tęczyńscy, op. cit., jw.

57 AKMKr, Acta officialia, t. 32, s. 125. Malarz Joachim to Joachim Libnau z Drossen na Śląsku, jeden z czołowych malarzy krakowskich pierwszej ćwierci XVI w. Prawo miejskie krakowskie uzyskał w 1496 r. za poręczeniem malarza Marcina Czarnego, z którym historycy sztuki łączą m.in. obraz Madonny z Jabłkiem (Mater Salvatoris) w kościele Bożego Ciała w Krakowie. Zob. K. Przybyszewski, Jerzy, malarz krakowski (1501-1520), „Sprawozdania Polskiej Akademii Umiejętności”, 50/1949, nr 10, s. 566-567; tenże, Marcin Czarny-późnogotycki malarz krakowski, „Studia Renesansowe”, t. III, s. 252-266; J. Gadomski, Gotyckie malarstwo tablicowe, Warszawa 1998, s. 84.

58 E. Zielińska, Malowana tablica z gotycka inskrypcją odkryta w prezbiterium kościoła Wniebowzięcia Najświętszej Maryi Panny w Kraśniku, w: Kościót Wniebowzięcia Najświętszej Maryi Panny w Kraśniku, op. cit., s. 63-66.
} 
handlu, kontaktach klasztoru z otoczeniem, etc. ${ }^{9}$ Sam prepozyt udzielił pożyczki m.in. Otwinowskim 5 maja I50I r. (50 florenów), przyjął zapis od Andrzeja z Potoku i jego żony Katarzyny z Opoki I6 października I502 r. (80 grzywien), od Apolonii, żony dziedzica Rzeczycy Andrzeja, w I504 r. i kilku innych benefaktorów. Wymieniają też Jana Rabsztyńskiego. W styczniu I5I2 r. prepozyt sprzedał ks. Janowi Pszonce, proboszczowi w Bystrzycy, za 24 grzywny dwie jatki w Lublinie, które klasztor otrzymał od rodziny ks. Jana z Lublina albo od niego samego. Jego pełnomocnikiem w tej sprawie był Zmarzłek z Lublina. Udzielane pożyczki i przyjmowane zapisy, wymiana ksiąg z kanonikami kapituły opatowskiej, zachowane pomniki piśmiennictwa i księgi drukowane, zawierane umowy, akty sprzedaży i wnoszone sprawy administracyjne w konsystorzach sandomierskim, lubelskim i krakowskim dowodzą, że klasztor cieszył się uznaniem w okolicy, pozostawał w dobrych relacjach z rodziną fundatorów, dziedzicami ościennych dóbr (Potok, Opoka, Leśnik, Rzeczyca, Blinów), duchowieństwem, mieszczanami kraśnickimi, lubelskimi, sandomierskimi oraz ludźmi rzemiosła (złotnik sandomierski Bartłomiej), rozwijał gospodarkę rolną i hodowlę, w której sporo uwagi poświęcano pszczelarstwu, wzniósł zespół monumentalnych murowanych budynków kościelno-klasztornych, kontynuował prace nad wystrojem artystycznym kościoła, dbał o kulturę umysłową, zachowanie dyscypliny konwentualnej i duszpasterstwo. Z nekrologu klasztornego kraśnickiego i krakowskiego wiemy, że prepozyt ustąpił z urzędu. Rezygnacja miała miejsce najwcześniej w I5I3 r., a najpóźniej w r. I5I9. W dokumentach ostatni raz prepozyt został wzmiankowany na urzędzie 28 października $\mathrm{I} 5 \mathrm{I} 2 \mathrm{r}^{60}$ Co było przyczyną rezygnacji, nie udało się ustalić. W okresie jego rządów konwent tworzyło ośmiu zakonników in sacris i jeden lub dwóch konwersów. W dokumencie z 4 maja I50I r., który jest jednym z najstarszych świadectw aktywności kancelarii klasztornej, wymieniono z imienia ośmiu kanoników biorących wówczas udział w posiedzeniu kapituły konwentualnej. Pogrzeby były co najmniej dwa, a mianowicie ks. Jana z Lublina, posiadającego magisterium artium, oraz konwersa Błażeja. Nadmienić nadto trzeba, że pod rządami prepozyta Michała, być może po jego pobycie w Krakowie w I5IO r., w wykazie zmarłych konfratrów z klasztoru krakowskiego przy nazwisku księdza Stanisława Kazimierczyka dodano: miraculis clarens (jaśniejący cudami). Ta mała glossa jest jedyną informacją źródłową potwierdzającą kult tego świętego w pierwszej ćwierci XVI w. W nekrologu zgon prepozyta odnotowano pod 3I grudnia $1523 \mathrm{r}^{6 \mathrm{I}}$

\section{Ks. Maciej ( 1520/1521)}

O jego pochodzeniu i młodości nie udało się pozyskać żadnych informacji. W marcu I49I r. był już po święceniach kapłańskich, pełnił obowiązki prokuratora konwentu. Wraz z prepozytem Janem był w Lublinie, gdzie z mistrzami sztuki murarskiej Stanisławem i Marcinem zawarto porozumienie w sprawie dostarczenia do Kraśnika kamienia ciosanego ${ }^{62}$. W dokumencie wystawionym przez klasztor 4 maja I5OI r. wymieniono go na piątym miejscu $^{63}$. Progi furty klasztornej przekroczył zatem najpóźniej ok. I485 r., mając za sobą

59 E. Zielińska, Kultura intelektualna, op. cit., s. 54.

60 AAL, Acta consistorii foranei Lublinensi, sygn. 17, s. 143.

${ }_{61}$ BUMCS III 608, s. 74; ANK, ms K 888, n. 230; ABC, Memoriale, s. 8; E. Zielińska, Nekrolog, s. 111.

${ }^{62}$ ADL, Acta consistorii foranei Lublinensi, sygn. 5, k. 253.

${ }^{63}$ ABC, Reformationes Conventuum, s. 157; E. Zielińska, Kultura intelektualna, op. cit., s. 65. 
studia uniwersyteckie. Studia odbył bez wątpienia w Krakowie, ale identyfikacja w metryce i w księdze promocji jest utrudniona ze względu na nieznane miejsce pochodzenia. Nie jest wykluczone, że pochodził z Lublina. Nie udało się ustalić, od kiedy był prepozytem. Z urzędu zrezygnował na początku listopada I52I r., a w każdym razie 25 listopada biskup krakowski Jan Konarski zatwierdził już wybór następcy ${ }^{64}$. Po ustąpieniu z urzędu żył jeszcze jedenaście lat, co dowodzi, że przyczyną rezygnacji był nie tyle stan zdrowia, co sytuacja wewnątrzklasztorna lub okoliczności zewnętrzne, których rozwiązanie przerastało jego możliwości. W suplice o zatwierdzenie wyboru jego następcy przedłożonej biskupowi przez konwent nie było jego imienia. Pozwala to wnioskować, że w kapitule wyborczej nie wziął udziału albo przebywał w tym czasie poza klasztorem. Nekrolog konwentualny odnotował jego śmierć pod 26 maja 1532 r. $^{65}$

\section{Ks. Lukasz (1521-1525)}

O jego młodości, koneksjach rodzinnych i wykształceniu nic nie wiadomo. Do klasztoru wstąpił po I50I r. Na urząd został wybrany po rezygnacji prepozyta Macieja. Biskup krakowski Jan Konarski zatwierdził wybór 25 listopada I52I r. ${ }^{66} \mathrm{~W}$ kapitule konwentualnej, która dokonała wyboru, zasiadało obok niego tylko czterech kanoników, a mianowicie: ks. Michał, ks. Albert, ks. Tomasz oraz ks. Franciszek. O aktywności prepozyta, jak również o klasztorze i parafii w okresie jego rządów wiemy niewiele. Skromna liczba zakonników biorących udział w kapitule wyborczej i nieobecność w jej składzie ks. Macieja, który dopiero co złożył rezygnację z urzędu prepozyta, zdaje się jednak sugerować jakiś kryzys w klasztorze spowodowany być może z jednej strony nieoczekiwanymi zgonami, a z drugiej problemami związanymi z utrzymaniem dotychczasowej dyscypliny i kultury wewnętrznej. Domniemanie o istnieniu problemów wewnętrznych wzmacnia późniejsza wzmianka o wizytacji przeprowadzonej w klasztorze jesienią I522 lub wiosną I523 r. z polecenia biskupa Jana Konarskiego ${ }^{67}$. W tym krótkim czasie rządów prepozyta Łukasza w klasztorze zmarło trzech zakonników: ks. Albert (I523), dawny prepozyt ks. Michał (I523) oraz ks. Franciszek (I524). Ten ubytek w składzie konwentu był najpewniej powodem, dla którego z konwentu krakowskiego przybył tu m.in. ks. Albert Casimirita. Ostatnia wzmianka o urzędowaniu prepozyta pochodzi z 25 czerwca I525 r. Tego dnia zawarł ugodę z Janem Węgrzynem z Trzydnika co do łąki w tej miejscowości, używanej przez klasztor w zamian za dług zaciągnięty niegdyś przez Andrzeja z Trzydnika ${ }^{68}$. Wkrótce potem prepozyt złożył rezygnację z urzędu, bo 25 lipca 1525 r. biskup krakowski Piotr Tomicki zatwierdził wybór następcy ${ }^{69}$. Nekrologi kraśnicki i krakowski nie wymieniają go wśród zmarłych konfratrów, co sygnalizuje, że zmarł poza klasztorem. Nie jest wykluczone, że przeszedł do Kłobucka, by tam, po

\footnotetext{
${ }^{64}$ AKMKr, Acta Episcopalia, t. 8, k. 131.

${ }_{65}$ BUMCS, sygn. III 600, s. 74; ANK, ms K 888, n. 230; ABC, Memoriale, s. 8; VAKA, Liber Canonicorum Regularium Conventus Vilnensis in Antocollo ad Ecclesiam Sancti Petri, sygn. F. 1 ep. 5b 8; S. Ranatowicz, Casimiriae civitatis, op. cit., k. 40v; K. Łatak, Kongregacja krakowska, op. cit., s. 111; E. Zielińska, Kultura intelektualna, op. cit., s. 67; taż, Nekrolog, s. 106.

${ }_{66}$ AKMKr, Acta Episcopalia, t. 8, k. 131.

67 O wizytacji tej nadmienia się w aktach wizytacji przeprowadzonej w 1592 r. z polecenia biskupa Jerzego Radziwiłła.

${ }_{68}$ BGUMCS, sygn. III 608, s. 75; E. Zielińska, Kultura intelektualna, op. cit., s. 55.

${ }_{69}$ AKMKr, Acta Episcopalia, t. 14, k. 23v.
} 
nieoczekiwanej śmierci ks. Łukasza z Wielunia, objąć urząd prepozyta. Jeśli domniemanie jest słuszne, to prepozyt pochodził z Kunowa i zmarł w Kłobucku w I543 r. ${ }^{70}$

\section{Ks. Jan Chryzostom (1525-1531)}

Do klasztoru wstąpił najwcześniej w I52I r. albo nie wziął udziału w kapitule, która zebrała się w listopadzie tego roku, by wybrać nowego prepozyta po rezygnacji przedłożonej przez ks. Macieja. Bardziej prawdopodobne wydaje się to drugie. Po rezygnacji prepozyta Łukasza z urzędu w I525 r. kapituła wybrała go na wakujące stanowisko. W kapitule wyborczej obok niego wzięło udział najmniej czterech kanoników: ks. Jakub, ks. Maciej, ks. Tomasz i ks. Andrzej z Bodzentyna. Nie wiadomo, czy były prepozyt Łukasz był jeszcze w klasztorze. Biskup krakowski Piotr Tomicki zatwierdził wybór 25 lipca $^{71}$. W okresie jego rządów w klasztorze zmarło trzech kanoników: Albert z Krakowa (1526), Jakub (1528) i wieloletni prowizor pasieki ks. Tomasz (1530). Prokuratorem konwentu był najpierw ks. Maciej (I3 III I528) 72 a następnie ks. Andrzej, który w I529 r., jak sygnalizuje Liber retaxationum diecezji krakowskiej, informował biskupstwo o dochodach klasztoru i regulował należne diecezji subsydium ${ }^{73}$. Z przedłożonej relacji wiemy, że roczne dochody klasztoru szacowano wówczas na 48 grzywien i 8 groszy. Potencjał finansowy prepozytury był jednak znacznie większy, skoro I3 marca $1528 \mathrm{r}$. konwent udzielił pożyczki w wysokości 60 grzywien Annie i Andrzejowi Ostrowskim, dziedzicom Leśnika ${ }^{74}$. Relacja o dochodach przedłożona przez kanonika Andrzeja potwierdza też działalność szkoły parafialnej. Rektor za swoją pracę pobierał wówczas od prepozyta sześć grzywien ${ }^{75}$. Ok. 1527 r. przy wsparciu finansowym Jana Gabrielowica Tęczyńskiego rozpoczęto rozbudowę kościoła i prace nad wnętrzem korpusu nawowego, które jak informuje data pozostawiona na ambonie, trwały jeszcze w I54I $\mathrm{r}^{76}$ Prepozyt zrezygnował z urzędu w październiku I53I r. Rezygnację, którą przyjęto 23 października, przedłożył biskupowi krakowskiemu za pośrednictwem swojego prokuratora magistra Szymona z Kalisza, zaś sam akt rezygnacji spisał notariusz publiczny Stanisław z Sandomierza ${ }^{77}$. Po ustąpieniu z urzędu żył jeszcze trzynaście lat, co sugeruje, że rezygnacja była dobrowolna, ale jej przyczyny poważne. Nekrolog konwentu odnotował jego zgon pod 5 lipca $1544 \mathrm{r}^{78} \mathrm{~W}$ nekrologu konwentu krakowskiego przy jego imieniu nie odnotowano, że niegdyś był prepozytem.

\footnotetext{
70 K. Łatak, Kongregacja krakowska, op. cit., s. 111; E. Zielińska, Kultura intelektualna, op. cit., s. 67.

71 AKMKr, Acta Episcopalia, t. 12, k. 218v.

72 ADS, Acta Officialia, t. 101, k. 408.

73 E. Zielińska, Kultura intelektualna, op. cit., s. 57.

74 ADS, Acta Officialia, t. 101, k. 408.

75 Księga dochodów beneficjów diecezji krakowskiej z roku 1529 (tzw. „Liber Retaxationum”), wyd. Z. Leszczyńska-Skrętowa, Kraków 1968, s. 455-456.

76 Kościót Wniebowzięcia Najświętszej Maryi Panny w Kraśniku, Kraśnik 2013.

77 AKMKr, Acta Episcopalia, t. 14, k. 23v.

78 BGUMCS, sygn. III 608, s. 121; ANK, K 888, s. 75; ABC, Memoriale, s. 8; VAKA, Liber Canonicorum Regularium Conventus Vilnensis, jw.; K. Łatak, Kongregacja krakowska, op. cit., s. 111; E. Zielińska, Kultura intelektualna, op. cit., s. 68; taż, Nekrolog, 106.
} 


\section{Ks. Andrzej z Bodzentyna (1531-1535)}

Do klasztoru wstąpił po I52I r. Wydaje się, że to z nim należy kojarzyć ks. Andrzeja, który w I529 r. przedkładał w kurii krakowskiej informacje o dochodach rocznych prepozytury. Najpewniej był wówczas przeorem lub prokuratorem konwentu ${ }^{79}$. Na urząd prepozyta został wybrany po rezygnacji ks. Jana Chryzostoma, a wybór został zatwierdzony przez biskupa krakowskiego Piotra Tomickiego 23 października I53I r. ${ }^{80}$ Brak źródeł nie pozwala na pełne ukazanie jego aktywności ani wydarzeń z życia klasztoru i parafii w tym okresie. Domniemywać można, że już w okresie jego rządów z inicjatywy Jana i Stanisława Tęczyńskich trwała przebudowa zachodniej części korpusu nawowego kościoła. Nekrolog konwentualny odnotował pod 26 maja I532 r. śmierć byłego prepozyta Macieja. Z akt sądowych wiemy natomiast, że 5 lutego I533 r. rajca lubelski Walenty wytoczył proces prepozytowi i klasztorowi o niedotrzymanie warunków kontraktu na dostarczenie miodu ${ }^{81}$. Potwierdza to kolejny raz istnienie pasieki klasztornej oraz produkcji miodu na szerszą skalę, co można uznać za specyfikę gospodarki klasztornej tego okresu. W ostatnich dniach czerwca lub na początku lipca 1535 r. prepozyt ustąpił jednak z urzędu, albowiem I7 lipca tego roku biskup krakowski Piotr Tomicki zatwierdził już wybór następcy ${ }^{82}$. Po rezygnacji ks. Andrzej pozostał w klasztorze. Nekrolog klasztorny odnotował jego śmierć pod dniem 24 lutego $1537 \mathrm{r}^{83}$

\section{Ks. Andrzej ze Słupczy (1535-1561)}

Pochodzenie prepozyta wiążę nie tyle ze Słupcą wielkopolską, którą w tamtym czasie pisano również Słupcza, co ze wsią Słupcza w parafii Dwikozy, w powiecie sandomierskim. Wywodził się najprawdopodobniej z dziedziców tej wsi, stemplujących się herbem Rawicz. Do klasztoru wstąpił po I52I r., a przed rokiem I530, co sugeruje, że na świat przyszedł ok. 1500 r. O jego aktywności w klasztorze przed wyborem na urząd prepozyta nie udało się znaleźć żadnych informacji. Po rezygnacji prepozyta Andrzeja z Bodzentyna kapituła konwentualna wybrała jego na ten urząd. Biskup krakowski Piotr Tomicki zatwierdził wybór I7 lipca $1535 \mathrm{r}^{84} \mathrm{Na}$ okres jego rządów przypada dokończenie prac nad przebudową i wystrojem korpusu nawowego kościoła oraz budowa monumentalnych stalli kanonickich w prezbiterium, z których do naszych czasów zachowały się jedynie sedilia ${ }^{85}$. W ramach innowacji w korpusie nawowym urządzono dwie kaplice w stylu wczesnorenesansowym, wzniesiono chór muzyczny, a także marmurową ambonę, na której umieszczono napis: Sub Anno Domini I54I. Wykonawcy, jak twierdzi Michał Wardzyński, pochodzili z Krakowa, natomiast kamień sprowadzono ze Starej Lubowli na Spiszu. Kaplice i urządzone w nich ołtarze Przemienienia Pańskiego oraz św. Tekli mógł konsekrować sufragan krakowski

\footnotetext{
79 Księga dochodów beneficjów diecezji krakowskiej z roku 1529, op. cit., s. 455.

80 AKMKr, Acta Episcopalia, t. 12, k. 218v; t. 13, k. 477; t. 14, k. 23v.

81 AAL, Acta consistorii foranei Lublinensi, t. 12, k. 205v-206.

82 AKMKr, Acta Episcopalia, t. 14, k. 23v.

83 BGUMCS, sygn. III 608, s. 121; ABC, Memoriale, s. 8; VAKA, Liber Canonicorum Regularium Conventus Vilnensis, jw.; K. Łatak, Kongregacja krakowska, op. cit., s. 111; E. Zielińska, Kultura intelektualna, op. cit., s. 68; taż, Nekrolog, s. 104.

84 AKMKr, Acta Episcopalia, t. 13, k. 477.

${ }^{85}$ K. Łatak, Kongregacja krakowska, op. cit., s. 108; E. Zielińska, Kultura intelektualna, op. cit., passim; Kościót Wniebowzięcia Najświętszej Maryi Panny w Kraśniku, jw.
} 
Dominik Małachowski w I540 r. W tym bowiem roku w listopadzie, jak monitują późniejsze akta wizytacji (I748), biskup konsekrował drewniany kościół szpitalny w Kraśniku, wzniesiony po I53I r. z fundacji Jana Gabrielowica Tęczyńskiego ${ }^{86}$. W I544 r. porządkowano także księgozbiór, czego śladem jest m.in. oprawa mszału z XV w., przechowywanego dzisiaj w Bibliotece Seminarium Duchownego w Lublinie ${ }^{87}$. Kilka ksiąg darowali konwentowi sami Tęczyńscy, co poświadczają oprawy z ich superekslibrisami ${ }^{88}$. W październiku I549 r. zmarł Stanisław Gabrielowic Tęczyński, dziedzic Batorza, którego pochowano w Kraśniku w kaplicy Przemienienia Pańskiego. Może to sugerować, że budowę tej kaplicy właśnie on finansował. W maju I552 r. zmarł Jan Gabrielowic Tęczyński, dziedzic Kraśnika. Pochowano go w kaplicy św. Tekli, gdzie wystawiono mu też nagrobek ze znakomitą płytą figuralną, którą wykonano w jednej z włoskich pracowni w Krakowie, a kamień sprowadzono ze Starej Lubowali $^{89}$. Gospodarka w okresie rządów prepozyta rozwijała się stabilnie, aczkolwiek nie obyło się bez momentów cierpkich. Ok. I550 r. miała miejsce tak duża powódź, że zniszczyła zupełnie stawy rybne, których nie odbudowano przed 1592 r..$^{\circ}$ Klasztor czerpał dochody z folwarków, czynszów, cła, danin, ofiar, handlu. Dnia I marca I550 r. król Zygmunt August potwierdził klasztorowi przywilej na pobieranie cła z Kraśnika i Urzędowa ${ }^{91}$. Zespół budynków - kościół i klasztor - prezentowały się monumentalnie i okazale na tle zabudowy miasta, a także okolicznych parafii i dworów. Duszpasterstwo odpowiadało potrzebom, a liturgię cechował splendor, co w jakiejś mierze potwierdza spisana w klasztorze (I537-I546) przez ks. Jana z Lublina zachowana tabulatura muzyczna, przechowywana dzisiaj w zbiorach PAU/PAN w Krakowie ${ }^{92}$. Kanonicy udzielali się także na zewnątrz, miedzy innymi w Kiełczewicach, co poświadczają umowy prepozyta z tamtejszym proboszczem zawarte W lipcu 1536 r. oraz w marcu I543 r.93 W I556 r. Jakub Sieneński lokował miasto Radomyśl i wybudował tam niewielki drewniany kościół. Opiekę duszpasterską nad kościołem do czasu uregulowania jego statusu kanonicznego prowadzili kanonicy kraśnickiego konwentu ${ }^{94}$. Prepozyt utrzymywał też regularne kontakty z Krakowem, co potwierdzają wpisy w nekrologach obu konwentów. W okresie jego rządów w klasztorze działał i zmarł przywołany już ks. Jan z Lublina (+I4.XI.I552), wybitny muzyk i organista, po którym pozostała tabulatura muzyczna. Nekrolog kraśnicki odnotował zgon prepozyta pod dniem I2 listopada, natomiast nekrolog krakowski pod dniem 7 stycznia I56I r. z uwagą, że był prepozytem naprawdę godnym (vere dignum). Jeśli w zapisie nekrologu kraśnickiego nie ma pomyłki co do daty dziennej zgonu, to prepozyt musiał zrezygnować z urzędu co najmniej w styczniu I56I r., gdyż w lutym z tytułem prepozyta występował już ks. Jan Pomorzański ${ }^{95}$.

\footnotetext{
${ }^{86}$ AKMKr, Visitationes, t. 48, s. 158.

87 E. Zielińska, Kultura intelektualna, op. cit., passim.

88 Tamże.

${ }^{89}$ Kościół Wniebowzięcia Najświętszej Maryi Panny w Kraśniku, op. cit., passim.

90 AKMKr, Visitationes, t. 45, k. 91v-95.

91 E. Zielińska, Kultura intelektualna, op. cit., passim.

92 Tamże.

93 AAL, Acta consistorii foranei Lublinensi, t. 9, k. 157-157v, 167v-168, 185; t. 13, k. 92, $213 \mathrm{v}$.

94 Rocznik Diecezji Sandomierskiej 1994, s. 153.

95 BGUMCS III 608, s. 125; APK, ms K 888, n. 232; ABC, Memoriale, s. 11; VAKA, Liber Canonicorum Regularium Conventus Vilnensis, jw.; K. Łatak, Kongregacja krakowska, op. cit., s. 111; E. Zielińska, Kultura intelektualna, op. cit., s. 68; taż, Nekrolog, s. 110.
} 


\section{Ks. Jan Pomorzański (1561- 1580)}

O jego młodości i koneksjach rodzinnych nie ma pewnych informacji, aczkolwiek te, które udało się zebrać, sugerują, że wywodził się ze wsi Pomorzany w starostwie rabsztyńskim i parafii olkuskiej (dzisiaj dzielnica Olkusza). Urodził się ok. 1515 r. Do zakonu wstąpił jako duchowny diecezji krakowskiej. I lipca 1552 r. miał już święcenia niższe, był notariuszem w kurii krakowskiej, a Jan Boner, kasztelan chełmski, mąż Katarzyny Tęczyńskiej, prezentował go na prebendę zamku w Tęczynku, wakującej po rezygnacji biskupa chełmskiego Jakuba Uchańskiego ${ }^{96}$. Należał też do grona protegowanych przez dwór Jana Chrzciciela Tęczyńskiego, ostatniego z dziedziców Kraśnika, i bez wątpienia przy osobistym wsparciu hrabiego oraz Jana Bonera został tu prepozytem. Ks. Wincenty Smoczyński w niewielkiej publikacji na temat zamku tęczyńskiego nadmienił, że ks. Pomorzański wstąpił do klasztoru w 562 r. Tymczasem prepozytem był on już w lutym I56r r., co własnoręcznie zaznaczył na wyklejkach ksiąg zakupionych w Lublinie ${ }^{97} .22$ października $1562 \mathrm{r}$. w konsystorzu krakowskim przyjęto jedynie jego rezygnację z prebendy zamkowej w Tęczynku, którą złożył na piśmie 6 października za pośrednictwem kanonika katedry krakowskiej Zbigniewa Ziółkowskiego ${ }^{98}$. Do zakonu wstąpił zatem ok. $1560 \mathrm{r}$. i najprawdopodobniej z perspektywą objęcia prepozytury. Na okres jego rządów przypada sporo procesów. W marcu 1563 r. prepozyt procesował się z ks. Stanisławem, prepozytem kościoła szpitalnego w Urzędowie, o Io florenów zapisanych klasztorowi przez poprzedniego prepozyta tegoż szpitala, ks. Andrzeja. We wrześniu I563 r. proboszcz pniowski, ks. Marcin, oskarżył klasztor kraśnicki o zabór dziesięcin z Rzeczycy. Proces toczył się w Sandomierzu do 27 lipca 1565 r. W I568 r. klasztor procesował się z opactwem cystersów koprzywnickich (opat Jan Młodziejowski) o dziesięciny z Zakrzowa i Sułowa. Proces trwał od 28 maja do I października. $Z$ racji prowadzonych procesów prepozyt pojawiał się stosunkowo często w oficjalacie w Sandomierzu i w Lublinie ${ }^{99}$. Księgi czynności biskupów i oficjałów w Krakowie nie odnotowały jego obecności. W 1563 r. zmarł ostatni dziedzic dóbr kraśnickich z rodu Tęczyńskich - Jan Chrzciciel. Po jego śmierci zarząd dóbr spoczął najpierw w rękach wojewody bełzkiego Andrzeja Tęczyńskiego, a po wygranym procesie w I579 r. przejęła je Katarzyna z Tęczyńskich (I544-I592), siostra Jana Chrzciciela oraz żona księcia słuckiego Jerzego Olelkowicza (153I-1578) a po jego śmierci Krzysztofa I Radziwiłła (1547-I603) ${ }^{100}$. Lata zawirowań wokół dziedziczenia dóbr kraśnickich to także okres przejmowania kościołów okolicznych parafii przez protestantów. W Popkowicach kościół został oddany protestantom przez samego Mikołaja Reya, w Pniowie protestantyzm zaprowadził dziedzic Jan Słupecki ze Słupczy. Ok. 1570 r. w rękach protestantów znalazły

\footnotetext{
${ }_{96}$ AKMKr, Acta Officialia, t. 83, k. 809: „Ad altare seu prebendam in Arce Thenczin sittam per liberam resignacionem R[everendissi]mi in Christo Patris et D[omi]ni Jacobi Uchański e[pisco]pi Chelmen[sis] Venerabilem Joannem Pomorzański clericum in minoribus ordinis ad presentacionem Magnifici et Generosi D[omi]ni Joannis Bonar de Balicze castellani Chelmensis".

97 Opera Joannis Driedonis empta sunt per me Joannem Pomorzański Praepositum Crasnicen[sem] Anno D[omi] ni 1561 mense Februario Lublini. Zob. L. Zalewski, Biblioteka, s. 12.

98 AKMKr, Acta Officialia, t. 104, k. 769. Prebendę objął po nim ks. Feliks Czerski, a prezentował go Jan z Tęczyna, starosta lubelski.

99 ADS, Acta Officialia, t. 105, s. 30, 33, 41, 45, 60, 99, 101, 105, 236, 447, 485, 489, 494, 531, 539, 542, 554, 588, 609.

${ }^{100}$ E. Zielińska, Kultura intelektualna, op. cit., s. 3; J. Kurtyka, Latyfundium tęczyńskie. Dobra i wtaściciele (XIV-XVII wiek), Kraków 1999.
} 
się nadto kościoły parafialne w Rybitwach, Goraju i Wysokiem ${ }^{101}$. Zamiana kościołów katolickich na zbory protestanckie nie zawsze dokonywała się spokojnie. Z późniejszych akt wizytacji wiemy, że w Pniowie zamordowano pastora, a paramenty liturgiczne kościoła w Wysokiem schowano w kościele w Targowisku ${ }^{102}$. Zawirowania te przekładały się mimo wszystko także na życie klasztoru oraz parafii w Kraśniku. W pierwszym rzędzie zaczęły się zmniejszać dochody, gdyż coraz rzadziej wpływały sumy zapisanych niegdyś czynszów, czynsze z ulokowanych kapitałów, missalia i dziesięciny. Stawy rybne zniszczyła powódź, nie produkowano już miodu w takich ilościach jak wcześniej, niektóre z pól i łąk znalazły się w rękach dzierżawcy dóbr kraśnickich ${ }^{103}$. Dyscyplina klaustralna, liturgia, nauczanie i duszpasterstwo utrzymywały się jednak w normie, a przynajmniej w zachowanych aktach czynności biskupów krakowskich oraz ich oficjałów nie ma w tym zakresie niczego, co pozwoliłoby wnioskować inaczej. Działała szkoła parafialna, a jej absolwentami mogli być pochodzący z Kraśnika Albert, który w kwietniu I575 r. przyjął święcenia i objął wikariat w kolegiacie sądeckiej, Marcin, który święcenia przyjął w maju I584 r. i objął mansjonarię na zamku w Lublinie oraz Piotr, który w latach 1594-I595 był rektorem szkoły w Mielcu. Kanonicy nadal udzielali się w Radomyślu, gdzie wciąż kwestia kościoła nie była uregulowana kanonicznie, a także zastępowali w obowiązkach ks. Mikołaja, prepozyta kościoła szpitalnego w Kraśniku. Zapis w nekrologu pozwala domniemywać, że prepozyt Mikołaj ostatnie dni swojego życia spędził w klasztorze. O ewentualnych pracach prowadzonych w tym czasie w obrębie zespołu klasztornego, poza budową nagrobka Jana Chrzciciela Tęczyńskiego, nie mamy informacji. Nie wiemy też nic o reakcji klasztoru i jego zakonników na przebieg i decyzje soboru trydenckiego, który w tym czasie zakończył obrady, a jego dekrety zostały przyjęte w Polsce. Wiemy za to, że prepozyt kupował sporo książek, które dzisiaj są przechowywane w zbiorach Biblioteki Seminarium Duchownego w Lublinie ${ }^{104}$. Okres jego rządów uświetniała działalność organisty ks. Walentego z Sędziszowa (+1572), kaznodziei ks. Jana z Turobina (+I574) oraz ks. Adama Rzeczyckiego, który na wyklejkach swoich ksiąg pozostawił sporo notat o treści sentencjonalnej, a także odnoszących się do wydarzeń politycznych w drugiej połowie XVI w. Ostatnia wzmianka źródłowa o prepozycie pochodzi z 1578 r., a stanowi ją nota proweniencyjna zamieszczona na jednej z zakupionych przez niego książek. Prepozyt zmarł najpewniej w I580 r., aczkolwiek jego zgonu nie odnotowano ani w nekrologu kraśnickim, ani w nekrologu krakowskim ${ }^{105}$.

\section{Ks. Stanisław Otrębka [Otremba] (1580-1584)}

Pochodził najprawdopodobniej z Wolbromia, gdzie Otrębkowie (Otrombka, Otrembka, Otrąbka) należeli do rodzin patrycjuszowskich. W I545 r. zakupił jedną ze swoich ksiąg - kazania wydane w Kolonii w 535 r., która po kasacie klasztoru trafiła do zbiorów Biblioteki Seminarium Duchownego w Lublinie ${ }^{106}$. Wnioskować zatem można, że prepozyt urodził się najpóźniej ok. 1520 r. W latach 1575-1578 kupował sporo książek o charakterze

\footnotetext{
101 AKMKr, AV, 1; AVCap, 65.

102 Tamże.

103 AKMKr, Visitationes, 1, k. 33-36.

104 L. Zalewski, Biblioteka, op. cit., passim; E. Zielińska, Kultura intelektualna, op. cit., passim.

105 K. Latak, Kongregacja krakowska, op. cit., s. 111; E. Zielińska, Kultura intelektualna, op. cit., s. 68.

${ }^{106}$ L. Zalewski, Biblioteka, op. cit., jw.; E. Zielińska, Kultura intelektualna, op. cit., s. 98.
} 
kaznodziejskim, w tym Postillę katoliczna Jakuba Wujka z I574 r., co pozwala wnosić, że mógł pełnić obowiązki kaznodziei ${ }^{107}$. Prepozytem został najwcześniej w I580 r. W okresie jego rządów klasztor przeżywał pewne trudności dyscyplinarne i materialne. Prowincjał jezuitów Jan Paweł Campianus w liście z I4 września I582 r. do nuncjusza apostolskiego w Warszawie, Alberta Bolognettiego, pisał, że klasztor kanoników kraśnickich funkcjonuje w nieładzie, a księżna słucka Katarzyna myślała już o wymianie kanoników regularnych na jezuitów. Z uznaniem i zachwytem wyrażał się natomiast o samym zespole budynków - klasztorze i kościele (bellissimo mansterio, molto bella chiesa) - w których widział kolejne kolegium jezuickie ${ }^{\mathrm{ro}}$. Do usunięcia kanoników regularnych z Kraśnika jednak nie doszło. Sporo kłopotów nastręczyli w tym czasie konwentowi kanonickiemu cystersi opactwa koprzywnickiego, których własnością były wsie Zakrzów i Sułów, aczkolwiek należące do parafii kraśnickiej. Po 1576 r., a przed r. I592, opat Mikołaj Luboracki wzniósł w Zakrzowie drewniany kościół pod wezwaniem św. Mikołaja, osadził przy nim duchownego i zaczął organizować tu parafię. Mieszkańcom wszystkich wsi zabronił oddawać dziesięcin, a także uczęszczać do kościoła w Kraśniku ${ }^{109}$. Prepozyt Otrębka próbował bronić praw parafii kraśnickiej do Zakrzowa i Sułowa, ale niewiele mógł zdziałać. Opat miał silniejsze umocowanie w kręgach kościelnych i politycznych. W I584 r. książę słucki Aleksander, właściciel Kraśnika, uchylił prawo „de non tolerandis Judaeis" "Io. Odtąd Żydzi mogli swobodnie osiedlać się w miasteczku, tworząc dość szybko znaczącą pod względem demograficznym i ekonomicznym kolonię. Klasztor, jak pokażą późniejsze wizytacje biskupie i inne źródła historyczne, wcale nierzadko korzystał z ich usług, głównie w zakresie obrotu finansami, chociaż współistnienie dwóch kultur religijnych - chrześcijaństwa i judaizmu - powodowało także pewne napięcia w mieście, co monitują wizytacje kościelne od I6I7 r. ${ }^{\text {II }}$ Nekrolog klasztoru kraśnickiego odnotował zgon ks. Stanisława pod I8 grudnia I584 r. W nekrologu klasztoru krakowskiego oraz późniejszym nekrologu klasztoru wileńskiego spisanym w oparciu o nekrolog krakowski jego zgon datowano na rok $1585^{112}$.

\section{Ks. Andrzej Zagórski (1585-1593)}

O jego pochodzeniu, koneksjach rodzinnych i wykształceniu niewiele wiemy. Zebrane dotąd informacje źródłowe zdają się przekonywać, że pochodził z Blinowa, z rodziny tamtejszych dziedziców. Nie udało się ustalić, kiedy wstąpił do klasztoru. Święcenia kapłańskie przyjął przed 1573 r. w Krakowie. Na urząd prepozyta został wybrany w ostatnich dniach grudnia I584 lub na początku stycznia I585 r. W każdym razie z tytułem prepozyta wystąpił po raz pierwszy I kwietnia I585 r., gdy oblatował w Urzędowie dokument papieskiej konfirmacji fundacji klasztoru, wystawiony 9 kwietnia I487 r. przez komisarza papieskiego opata

\footnotetext{
107 Tamże.

108 Monumenta Poloniae Vaticana, t. V, „Series Nuntiaturae Poloniae”, ed. Alberti Bolognetti Nuntii Apostolici in Polonia Epistolarum et Actarum pars I aa. 1581-1582, ed. E. Kuntza, C. Nanke, Kraków 1923-1933, s. 491.

109 AKMKr, AV 1, s. 33-35; AVCap 31, s. 210-211.

110 E. Zielińska, Kultura intelektualna, op. cit., s. 55.

111 AKMKr, AV 1, s. 32-33: ,[...] in eodem villa proprio motu et autoritate extruxit Ecclesiam novam ligneam tituli S[ancti] Nicolai quae iam extructa ornavit et per hoc dismembrationem ab Ecclesia Monasterii Krasnicensis fecit". 112 ANK, K 888, n. 230; Memoriale, s. 8; VAKA, Liber Canonicorum Regularium Conventus Vilnensis, jw.; K. Łatak, Kanonicy regularni, op. cit., s. 88; tenże, Kongregacja krakowska, op. cit., s. 111; E. Zielińska, Kultura intelektualna, op. cit., s. 98; taż, Nekrolog, s. 110.
} 
koprzywnickiego Jana, oraz dokument króla Władysława Jagiełły z lipca I403 r., potwierdzający nadanie kościołowi w Kraśniku przez Beatę Gorayską wsi Rzeczyca ${ }^{\text {I3 }}$. Dnia I8 lipca 1589 r. przyjmował w klasztorze wracającego do Wiednia arcyksięcia Maksymiliana III Habsburga (I558-16I8), przegranego pretendenta do tronu polskiego, którego Jan Zamoyski po bitwie pod Byczyną więził na zamku w Krasnymstawie ${ }^{114}$. Okres rządów prepozyta nie należał jednak do łatwych ani pod materialnym, ani pod duszpasterskim względem, co sygnalizuje protokół wizytacji przeprowadzonej w piątek I9 czerwca 1592 r. na zlecenie archidiakona zawichojskiego Marcina Szyszkowskiego ${ }^{115}$. Miasto było wówczas własnością prawosławnego księcia słuckiego Jana Symeona Olelkowicza (+I592); konwent tworzyło siedmiu kanoników (prepozyt, ks. Grzegorz z Grodźca, ks. Marcin z Mielca, ks. Adam z Chrobrza, ks. Stanisław z Jedlnej, ks. Albert Lupka, ks. Teofil Kłosiński z Kłobucka); w okręgu parafialnym wizytator odnotował miasto Kraśnik oraz wsie Stróża, Słodków, Buczyn, Rzeczyca, Wyżnianka, Suchynia, Zakrzów i Sułów, aczkolwiek dwie ostatnie należały tylko formalnie do parafii, bo opat cystersów koprzywnickich Mikołaj Luboracki, jak to zostało zauważone już wyżej, z pogwałceniem woli fundatorów parafii kraśnickiej i prawa kanonicznego wzniósł w Zakrzowie drewniany kościół, osadził przy nim duchownego (ks. Paweł z Bodzentyna) i utworzył niezależny ośrodek duszpasterski; uposażenie kościoła i klasztoru w ostatnich latach zmniejszyło się znacznie; tenutariusz dóbr kraśnickich Maciej Białyński, chorąży sochaczewski, nie oddawał żadnych dziesięcin i czynszów, a nadto braci krzywdził i gnębił (fratres infligit et opprimit); stawy klasztorne zostały zniszczone wiele lat temu przez wylew rzeki i dotąd nie odbudowane; łąki i pola w Trzydniku zostały odebrane przez dziedzica Mikołaja Jaskulskiego, z którym prepozyt procesował się wprawdzie, ale niewiele wskórał; dziesięcin z Zakrzowa i Sułowa nie oddawano od wielu lat. Sytuacja materialna klasztoru nie wyglądała najlepiej, co już na pierwszy rzut oka potwierdzał wygląd budynków. Folwarki klasztorne wizytator ocenił jako podupadłe, co być może wiązało się z brakiem rąk do pracy. Wnętrze kościoła nie zostało opisane, ale nie ozdabiało go więcej niż siedem ołtarzy: główny, św. Anny, św. Pawła Apostoła, św. Stanisława, św. Augustyna, św. Tekli, Przemienienia Pańskiego. Liturgię sprawowano regularnie i zgodnie z agendą prowincji gnieźnieńskiej z $1578 \mathrm{r}$. W ciągu tygodnia oficjum divinum recytowano, natomiast w niedziele i święta w całości śpiewano; msze święte odprawiano codziennie - prymarię, wotywę i sumę; kazania głoszono w niedziele i święta; katechizm - Ojcze nasz, Zdrowaś Maryjo, Przykazania Boże i inne - recytował z ludem kaznodzieja. Nie wspomniał wizytator o procesjach, ale musiano je odprawiać podobnie jak w innych kościoła dekanatu. Nie wspomniał też o ofiarach pobieranych od posług religijnych. Nie wydaje się jednak, by w Kraśniku żądano więcej niż w innych parafiach (Borów, Potok), czyli po groszu od chrztu, ślubu, wywodu (a quodlibet Sacramento). Wyjątek mógł stanowić pogrzeb ze względu na to, że liczył się czasami pochówek w podziemiach kościoła. Z ksiąg kościelnych, którymi dysponowała zakrystia, wymieniono nowy mszał, a także graduał, antyfonarz, dwa psałterze spisane na pergaminie, co sugeruje ich dawne pochodzenie; był nadto graduał nowy i księga responsoriów, ale tych nie używano. Wizytator zwizytował księgozbiór klasztorny i księgozbiory braci pod kątem dzieł heretyckich, ale tych nie zidentyfikował. Zaniedbań

\footnotetext{
113 ABC, Metrica Conventus, II, s. 672; E. Zielińska, Kultura intelektualna, op. cit., s. 48.

114 E. Zielińska, Kultura intelektualna, op. cit., s. 139.

115 AKMKr, AV 1, s. 33-35; AVCap 65, s. 467-469; AVCap 12, s. 10-12.
} 
duszpasterskich ani zgorszeń ze strony zakonników nie było. Szkoła parafialna działała, jej budynek był murowany. Rektor ze stopniem bakałarza artium miał wielu uczniów (habet plurimos scholares), a uczył ich pobożności, obyczajów oraz sztuk wyzwolonych (et eosdem in pietate, honestate moribus liberalibusque artibus instruit). Spośród książek używanych w szkole wizytator wymienił Colloquia Erazma z Rotterdamu. Kanonicy konwentu kraśnickiego udzielali się także w kościele szpitalnym w zastępstwie jego prepozyta ks. Piotra z Warki. Przesłuchiwani przez wizytatora burmistrz i rajcy miasta wydali klasztorowi i prepozytowi dobre świadectwo. W ramach zaleceń prepozyt został zobowiązany do podjęcia starań na drodze sądowej o odzyskanie zabranych siłą dóbr klasztornych ${ }^{116}$. W okresie rządów prepozyta Zagórskiego w klasztorze zmarł co najmniej jeden kanonik: Sebastian Wolik z Chodla (1587), natomiast śluby złożyło dwóch kandydatów: Adam z Chrobrza (1585) oraz Albert z Przybyszewa (I593). W I592 r. przez miasto i parafię przetoczyła się fala morowego powietrza ${ }^{\text {II7 }}$. Prepozyt zmarł I8 grudnia $1593 \mathrm{r}^{\mathrm{II8}}$ Nekrolog krakowski, w a ślad za nim późniejszy nekrolog wileński datowały jego śmierć na rok $1594^{\text {I19. }}$.

\section{Ks. Marcin Nawoyski z Mielca (1594-1607)}

Urodził się ok. I550 r. w Mielcu. Był synem Jana Nawojskiego, szlachcica herbu Korab. W dokumentach pisano go Navoius, Nawoiowicz, Navoyski, Mielecius, Mielecensis lub Mieleczki. Nauki początkowe pobierał zapewne w Mielcu, po czym krótko studiował na Wydziale Artium Uniwersytetu Krakowskiego ${ }^{120}$. Do klasztoru wstą̧ił nie później niż jesienią 1573 r. I7 września I575 r. otrzymał w Krakowie święcenia subdiakonatu, I7 marca 1576 r. święcenia diakonatu i 7 kwietnia 1576 r. święcenia kapłańskie z rąk sufragana Marcina Białobrzeskiego ${ }^{121}$. Po święceniach kapłańskich pełnił w klasztorze m.in. obowiązki kaznodziei. W nekrologu krakowskim nadmieniono, że był wybijającym się kaznodzieją (facundus praedicator) ${ }^{122}$. Na urząd prepozyta wybrano go w ostatnich dniach grudnia 1593 lub na początku stycznia I594 r. Biskup krakowski kard. Jerzy Radziwiłł zatwierdził wybór II stycznia I594 r. ${ }^{123}$ Rządy jego, jak sugeruje zestawienie pozyskanych informacji źródłowych, nie były spokojne. Zresztą sam prepozyt, jak się wydaje, nie należał do ludzi łatwego charakteru ani wyrozumiałych. Zachowane księgi miejskie odnotowały jego obecność w magistracie po raz pierwszy dopiero w kwietniu I602 r., gdy odbierał sumę 24 zł i Io gr zapisaną na kościół przez Małgorzatę Gliczankę ${ }^{124}$. W 1598 r. z polecenia kard. Jerzego Radziwiłła odbyła się wizytacja archidiakonatu zawichojskiego, w czasie której wizytator odwiedził

\footnotetext{
116 Tamże.

117 APL, Akta Miasta Kraśnika, sygn. 1, s. 50.

118 BGUMCS III 608, s. 125.

119 APK, K 888, n. 230; Memoriale, s. 8; VAKA, Liber Canonicorum Regularium Conventus Vilnensis, jw.; S. Ranatowicz, Casimiriae civitatis, op. cit., k. 26v; L. Zalewski, Biblioteka, op. cit., jw.; K. Łatak, Kanonicy regularni, op. cit., s. 88; tenże, Kongregacja krakowska, op. cit., s. 111.

${ }^{120}$ Album Studiosorum Universitatis Cracoviensis, t. 3 (1551-1589), s. 127.

121 AKMKr, Liber Ordinandorum ab Anno 1573 usque ad Annum Domini 1585, s. 47, 53.

${ }^{122}$ ABC, Memoriale, s. 8.

123 AKMKr, AVCap 12, s. 10.

124 APL, Akta Miasta Kraśnika, sygn. 2, s. 106, 115.
} 
także Kraśnik ${ }^{125}$. Stan techniczny kościoła i klasztoru nie budził zastrzeżeń. Wyposażenie zakrystii w szaty, księgi i naczynia liturgiczne było nadzwyczaj bogate. Wśród kielichów I2 było srebrnych i pozłacanych, a wśród szat kilka ornatów i kap tkanych złotem (auro plicatae, ex auro contextae). Przy parafii działała szkoła, a jej rektor otrzymywał rocznie 24 floreny oraz utrzymanie. Okręg parafialny tworzyły: Kraśnik z przedmieściami, Słodków, Struża, Suchynia, Wyżlica, Budzyń i Rzeczyca. W okręgu funkcjonował kościół szpitalny pw. Świętego Ducha, w który w zastępstwie prepozyta Piotra z Warki obsługiwali kanonicy, kaplica na zamku pw. Wniebowzięcia Najświętszej Maryi Panny, kaplica dopiero co wzniesiona przez pewnego Włocha (Bernard Calabrese) na użytek ubogich przy bramie miasta, a także miejsce (kaplica?) w Rzeczycy, w którym często zdarzały się cudowne wydarzenia (locus quem saepius claruisse miraculis). Zakonnicy skarżyli się jednak wizytatorowi na złe traktowanie i samowolę prepozyta. 9 czerwca I6oo r. prepozyt musiał stawić się w konsystorzu krakowskim przed administratorem diecezji, gdyż w klasztorze nie ustały nieporozumienia związane z wykonywaniem przez niego władzy ${ }^{\mathrm{I26}}$. Podjętych wówczas decyzji nie znamy. Trudności nie ustąpiły jednak, gdyż 4 maja I604 r. prepozyt znów musiał stawić się w Chodlu przed komisarzami biskupa krakowskiego kard. Bernarda Maciejowskiego - ks. Hieronimem Renczajskim, ks. Sebastianem Nucerinusem i ks. Marcinem Kłoczyńskim. Zakonnicy kraśniccy skarżyli się bowiem na złe traktowanie, braki w pożywieniu, braki w ubraniu. Skarga nie rozmijała się z rzeczywistością. Prepozyt został upomniany przez komisarzy i zobowiązany pod karami kościelnymi do sprawiedliwego uregulowania kwestii w ciągu trzech miesięcy ${ }^{127}$. Jeśli prepozyt dostosował się do wskazań komisarzy, to nie na długo. W marcu lub kwietniu I607 r. biskup Piotr Tylicki ponownie wysłał do Kraśnika komisarza. Po przeprowadzonej wizytacji prepozyt złożył rezygnację z urzędu, a biskup Tylicki przyjął ją 3I lipca I607 r. ${ }^{\text {I28 }}$ Rezygnacja była, jak się wydaje, rozwiązaniem polubownym. Prepozyt otrzymał przyzwolenie na zamieszkanie przy kościele szpitalnym w Kraśniku, zaś konwent zobowiązał się do wypłacania mu 40 grzywien rocznie na utrzymanie ${ }^{\mathrm{I} 29}$. Nekrolog odnotował jego zgon pod dniem 27 listopada I6I3 r. ${ }^{130}$

\section{Ks. Albert Sowiński Tarnovita (1607-1628)}

Pochodził z Tarnowa, stąd w dokumentach klasztornych pisano go najczęściej Tarnoviensis lub Tarnovita. Z nekrologu klasztornego oraz relacji ks. Stefana Ranatowicza wiemy, że jego nazwisko brzmiało Sowiński ${ }^{131}$. Z kolei w księdze egzaminów do święceń diecezji krakowskiej zapisano, że był synem Tomasza Kaczorowicza ${ }^{132}$. Nie jest wykluczone, że

\footnotetext{
125 AKMKr, AV, sygn. 12.

126 AKMKr, Acta Administratoralia, t. 8, s. 248.

127 AKMKr, AV 4, k. 159.

128 AKMKr, Acta Episcopalia, t. 38, k. 17v-18.

129 Tamże.

130 APL, Akta miasta Kraśnika, sygn. 1, s. 50; Akta miasta Kraśnika, sygn. 2, s. 106, 115; ANK, K 888, n. 230; ABC, Memoriale, s. 8; BGUMCS III 608, s. 125; VAKA, Liber Canonicorum Regularium Conventus Vilnensis, jw.; S. Ranatowicz, Casimiriae civitatis, op. cit., k. 26v; L. Zalewski, Biblioteka, op. cit., jw.; K. Łatak, Kanonicy regularni, op. cit., s. 88; tenże, Kongregacja krakowska, op. cit., s. 111; E. Zielińska, Kultura intelektualna, op. cit., s. 98; taż, Nekrolog, s. 110.

131 ABC, Memoriale, s. 330; S. Ranatowicz, Casimiriae civitatis, op. cit., k. 34v-35.

132 Księgi egzaminów, wyd. Z. Pietrzyk, n. 3437.
} 
w księdze egzaminów zapisano błędnie dane, ale być także może, że właściwe nazwisko ojca brzmiało Sowiński, a Kaczorowic to przydomek. Urodził się ok. I56o r. Nauki początkowe pobierał najpewniej w rodzinnym mieście, gdzie działała szkoła kolegiacka na znaczącym poziomie. W semestrze zimowym I58I r. rozpoczął studia na Wydziale Artium Uniwersytetu Krakowskiego ${ }^{133}$. Do zakonu wstąpił na przełomie I589/I590 r. Nowicjat odbył, śluby zakonne złożył i studium teologii niezbędne do święceń ukończył w klasztorze Bożego Ciała. Święcenia przyjmował kolejno w Krakowie: subdiakonat - I4 marca, diakonat - 23 maja i prezbiterat - 2I września 592 r. ${ }^{134}$ Po święceniach, aż do I6o3 r., rezydował w klasztorze krakowskim, udzielając się w parafii Bożego Ciała, co potwierdzają zachowane metryki chrztów ${ }^{135}$. 29 września I603 r. biskup krakowski zatwierdził jego wybór na urząd prepozyta klasztoru w Kurozwękach, gdzie zasłużył się kontynuacją prac nad ponownym urządzaniem wnętrza kościoła, zwróconego zakonowi w I595 r. przez protestantów po ponad dwudziestu latach i procesie sądowym ${ }^{136}$. I6 kwietnia I607 r. zrezygnował z prepozytury w Kurozwękach $^{137}$, by od 5 listopada I607 r. objąć urząd prepozyta w klasztorze w Kraśniku ${ }^{138}$. Dał się tu poznać przede wszystkim z osobistej pobożności. Dość często pojawiał się w urzędzie miasta w sprawach kościoła parafialnego oraz bractwa różańcowego ${ }^{\mathrm{I} 39}$. Bractwo założył Io września I609 r., a I6 grudnia uzyskał dla niego potwierdzenie z odpustami biskupa Piotra Tylickiego ${ }^{140}$. Od tegoż biskupa otrzymał w I6I4 r. potwierdzenie prawa do pobierania dziesięcin ze wsi Lipnik. Jesienią I6I8 r. prowadził spór sądowy z prepozytem kościoła szpitalnego Jakubem Kamińskim o prawa do łanów nazywanych Tokarzewskie i Wierzbickie w Kraśniku ${ }^{\mathrm{III}}$. Z tej racji dość często pojawiał się w Krakowie, co potwierdzają nie tylko akta oficjała, ale także wpisy w księdze bractwa Najświętszego Sakramentu przy kościele Bożego $\mathrm{Ciała}^{\mathrm{I} 42}$. Przeprowadził pewne remonty w klasztorze, rozpoczął prace nad zmianą wystroju wnętrza kościoła. Protokół wizytacji przeprowadzonej w lipcu I6I7 r. przez archidiakona Jakuba Piaseckiego nadmienia o nowym ołtarzu pw. Trójcy Przenajświętszej dopiero co wzniesionym w korpusie nawowym oraz kaplicy brackiej z ołtarzem, w którego nastawie znajdowała się nowa ikona Matki Bożej rzeźbiona i pozłocona ${ }^{\mathrm{I} 3}$. Słabszą stroną rządów prepozyta była natomiast ekonomia. Konwent, który liczył dziewięciu zakonników, skarżył

\footnotetext{
133 Album Studiosorum Universitatis Cracoviensis, t. 3 (1551-1589), s. 125.

134 AKMKr, Liber Ordinandorum, t. 2(1586-1596), s. 195; Księgi egzaminów, op. cit., s.103.

135 ABC, Liber Natorum et Baptisatorum in Parochia Sacratissimi Corporis Christi Casimiriae ad Cracoviam ab anno 1578 ad annum 1616, rkps, sygn. I-A-16.

136 AKMKr, Acta Officilialia, t. 113, s. 1353; S. Ranatowicz, Casimiriae civitatis, k. 34v-35; M.A. Gorczyński, Schema de Canonicis Regularibus Lateranensibus Congregationis Cracoviensis, op. cit., s. 107; K. Latak, Kongregacja krakowska, op. cit., s. 113.

137 AKMKr, Acta Episcopalia, t. 38, k. 61v.

138 AKMKr, Acta Episcopalia, t. 38, k. 38-38v.

139 APL, Akta miasta Kraśnika, sygn. 1, s. 239v; Akta miasta Kraśnika, sygn. 2, s. 230, 268-269, 270, 308-309, 312.

${ }^{140}$ Erygowane 10 IX 1609 r., zatwierdzone 16 XII 1609 r. Zob. AKMKr, AVCap 34, k. 13v; K. Łatak, Kongregacja krakowska, op. cit., s. 110; M. Kozera, Bractwa religijne $w$ archidiakonacie zawichojskim $w$ XVIII wieku, „Studia Sandomierskie", 20/2013, s. 14.

141 AKMKr, Acta Episcopalia, t. 41, k. 459, 477v, 489, 510-515. Proces rozpoczął się 3 IX 1618 r. i trwał do 24 X 1618 r. Czasami w konsystorzu reprezentował go przeor Albert Chamiec.

${ }^{142}$ ABC, Liber Vitae sive Album Dominorum Sodalium utriusque status et sexus Venerabilis Confraternitatis Sacratissimi Sacramenti Casimiriae ab Anno Domini 1551, rkps b. sygn., s. 21. Wraz z prepozytem wpisali się do księgi: ks. Augustyn Żochowicz i ks. Marcin Rzekiecki.

143 AKMKr, AVCap 34, k. 12-14v.
} 
się na brak kolegialności, nadmierną poufałość prepozyta z dworami okolicznej szlachty, zatrudnianie na folwarkach osób wątpliwej konduity moralnej, niewłaściwą gospodarkę finansami klasztornymi ${ }^{144}$. Biskup Marcin Szyszkowski zwrócił się zatem do prepozyta krakowskiego Marcina Kłoczyńskiego, którego znał doskonale jeszcze z okresu pracy w kurii kard. Jerzego Radziwiłła, o przeprowadzenie dodatkowej wizytacji i zreformowanie stosunków w klasztorze. Podstawę prawną wizytacji i reformy miał stanowić przywilej fundacji klasztoru, w którym wskazano klasztor macierzysty jako prawzór dyscypliny konwentu kraśnickiego, ale zwrócono się także do papieża Pawła V z prośbą o jego przyzwolenie. Bulla papieska zezwalająca na przeprowadzenie reformy i podporządkowanie klasztoru prepozyturze macierzystej w Krakowie została wystawiona 25 maja I6I8 r. Nie wiadomo, kiedy dotarła do Krakowa, ale wiadomo, że jej wykonanie miało miejsce w I620 r. Prepozyt podpisał wprawdzie dokument, ale w sposobie wykonywania władzy niewiele zmienił. Jesienią I627 r. prepozyt generalny kongregacji Marcin Kłoczyński zarządził więc kolejną wizytację w Kraśniku, którą przeprowadził przeor krakowski Jan Gelazy Zórawski. Wizytacja potwierdziła nienajlepszy stan klasztornych folwarków oraz podejmowanie operacji finansowych, które nie zawsze przynosiły zyski ${ }^{145}$. Kapituła generalna kongregacji, która zebrała się w Krakowie 28 października I628 r., po wysłuchaniu relacji wizytatora oraz dodatkowym przesłuchaniu trzech świadków wezwanych z Kraśnika, odwołała go z urzędu ${ }^{\mathrm{I} 46}$. Sam prepozyt nie przybył na kapitułę. Nie udało się ustalić, czy po odwołaniu z urzędu pozostał w Kraśniku, czy też został przeniesiony do innego klasztoru. Wina prepozyta nie była jednakże aż tak poważna, skoro kolejna kapituła generalna kongregacji, która zebrała się 20 października I63I r. wybrała go prepozytem w Suchej Beskidzkiej, gdzie przysłużył się do organizacji wewnętrznej klasztoru oddanego do użytku w I630 r., a przede wszystkim do urządzenia archiwum i biblioteki klasztornej. Udzielał się także w kościele filialnym w Krzeszowie ${ }^{\mathrm{I} 47}$. W czerwcu I635 r. odbyła się w Kraśniku kapituła generalna, która zgodnie ze statutami kongregacji winna była dokonać wyboru prepozytów dla wszystkich prepozytur lokalnych kongregacji w Małopolsce i w Wielkim Księstwie Litewskim. Z przyczyn bliżej nieznanych wybór prepozyta dla prepozytury suskiej przekazano kapitule konwentualnej konwentu generalnego w Krakowie. Kapituła konwentualna klasztoru Bożego Ciała nie wybrała jednak nowego prepozyta dla Suchej, lecz mianowała administratora w osobie ks. Patryka Milewskiego. Nie jest wykluczone, że takie rozwiązanie było podyktowane stanem zdrowia prepozyta, który zmarł 6 grudnia I636 r. w Krzeszowie, a pochowany został w Suchej, w podziemiach tutejszego kościoła. W zakonie uważano go za świątobliwego, oddanego modlitwie i kontemplacji, umartwieniu, służbie ubogim. Jego krótki żywot w oparciu o relację ks. Krzysztofa Łoniewskiego spisał ks. Stefan Ranatowicz. Pochlebnie pisał o nim także ks. Michał Akwilin Gorczyński w opublikowanej w I707 r. monografii kongregacji oraz Piotr Hiacynt Pruszcz. Klasztor krakowski polecił namalować jego portret, który zachował się do dzisiaj z legendą: Albertus Sowiński de Tarnów. Postać

\footnotetext{
144 AKMKr, AV 6, k. 65v-66.

145 Tamże.

146 ABC, Acta Capituli Generalis, k. 3. Świadkami byli m.in.: ks. Jan Baptysta Malanowski, przeor, ks. Wit Wnuczkowski oraz ks. Aleksander Bedoński.

147 APS, Liber natorum Krzeszów 1623-1647, s. 60-61.
} 
ks. Alberta Tarnovity przypomniała ostatnio Małgorzata Pęgier w artykule na temat żywotów świętych i świątobliwych, które znalazły się w kronice ks. Stefana Ranatowicza'48

\section{Podsumowanie}

Klasztor kanoników regularnych laterańskich w Kraśniku, ufundowany w maju I468 r. przez rodzinę magnacką Tęczyńskich i skasowany przez rosyjskie władze zaborcze jesienią I864 r., należał do ośrodków wyróżniających się w klimacie społeczno-religijnym i kościelnym Lubelszczyzny, stanowił jedno z głównych jej centrów kulturotwórczych i cywilizacyjnych. W przypadku samego Kraśnika odegrał fundamentalną rolę miastotwórczą. Tymczasem dotąd nie doczekał się całościowego opracowania swoich dziejów. Szczegółowe opracowanie monograficzne zyskała jedynie jego biblioteka, a w jej świetle kultura intelektualna konwentu, aczkolwiek tylko do 563 r. Nieco uwagi naukowej poświęcono jego kulturze muzycznej W związku z aktywnością ks. Jana z Lublina, autora monumentalnej tabulatury, który był kanonikiem tego konwentu i tu zmarł w I552 r., a ostatnio także kościołowi w związku z jego gruntowną restauracją podjętą w 2007 r. i kontynuowaną do roku 20I3. W zaproponowanym powyżej studium zająłem się rządcami klasztoru od jego fundacji do reformy przeprowadzonej w latach dwudziestych XVII w. Zebrany materiał źródłowy nie pozwolił naturalnie odpowiedzieć na wszystkie pytania sformułowane w fazie konstruowania projektu badawczego. Jednakże, w moim przekonaniu, to, co w jego świetle udało się zarysować, stanowi mimo wszystko znaczący wkład do studiów nad dziejami, kulturą oraz prosopografią tego klasztoru, a także jego miejscem i rolą w otoczeniu bezpośrednim i regionie.

\section{The governors of the Krasnik provost of Canons Regular of the Lateran from its foundation to the reform in the 17 th century Summary}

This article focuses on the prepositions of the monastery of the Canon Regular of the Lateran in Krasnik from its foundation in May I468 to the reform of I620-I627. Founded by Jan Rabsztynski of Teczyn, the owner of Krasnik goods, the monastery was considered as one of the prominent centers in terms of religions, social and cultural activity in the Lublin Region. Therefore, the studying of its history, culture and religious activities are important for getting to know the history of the city and its region. The culture of the monastery influenced the culture of the local environment, while the culture of the surroundings area left traces in the culture and activities of the monastery.

Keywords: Church prosopography, Canon Regular of the Lateran, history of culture, Krasnik, Region of Lublin

Nota o Autorze: Ks. prof. dr hab. Kazimierz Latak, profesor zwyczajny w Instytucie Nauk Historycznych UKSW, kierownik Katedry Nauk Pomocniczych Historii oraz Zakładu Archiwistyki.

\footnotetext{
148 ANK, sygn. K 888, n. 340; ABC, Memoriale, s. 330; S. Ranatowicz, Casimiriae civitatis, k. 34v-35; s. 125; M.A. Gorczyński, Schema de Canonicis, s. 110; K. Łatak, Kongregacja krakowska, s. 130; tenże, Ksiądz Stefan Ranatowicz, s. 176, 180; M. Pęgier, Żywoty świętych polskich w relacji Kroniki księdza Stefana Ranatowicza CRL (1617-1694), „Echa Przeszłości”, 14/2004, s. 59-60.
} 